Federal Reserve Bank of New York

Staff Reports

\title{
How "Unconventional" Are Large-Scale Asset Purchases? The Impact of Monetary Policy on Asset Prices
}

\author{
Carlo Rosa
}

Staff Report No. 560

May 2012

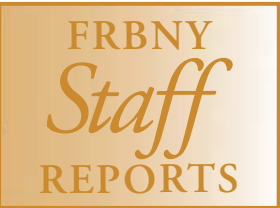

This paper presents preliminary findings and is being distributed to economists and other interested readers solely to stimulate discussion and elicit comments. The views expressed in this paper are those of the author and are not necessarily reflective of views at the Federal Reserve Bank of New York or the Federal Reserve System. Any errors or omissions are the responsibility of the author. 


\title{
How "Unconventional" Are Large-Scale Asset Purchases? The Impact of Monetary Policy on Asset Prices \\ Carlo Rosa
}

Federal Reserve Bank of New York Staff Reports, no. 560

May 2012

JEL classification: C14, E52, E58, F31

\begin{abstract}
This paper examines the impact of large-scale asset purchases (LSAP) on U.S. asset prices (nominal and inflation-indexed bonds, stocks, and U.S. dollar spot exchange rates) using an event study with intraday data. The surprise component of LSAP announcements is identified from Financial Times articles. Estimation results show that the LSAP news has economically large and highly significant effects on asset prices, even after controlling for the surprise component of the Fed's conventional target rate decision and communication about its future path of policy. This study documents that the cumulative financial market impact of the Fed's LSAP program is equivalent to an unanticipated cut in the federal funds target rate that ranges between zero (for three-month yields) and 197 basis points (for ten-year yields), with the response of stock prices and foreign exchanges lying within this interval. These point estimates are, however, surrounded by considerable uncertainty. By looking at the cross-asset reactions, this work concludes that, for most U.S. asset prices, the effects of asset purchases are not statistically different from an unanticipated cut in the fed funds target rate. Finally, the response of U.K. asset prices (excepting FTSE 100 stocks) to the Bank of England's gilt purchases is quantitatively similar to the reaction of U.S. asset prices to the Fed's asset purchases.
\end{abstract}

Key words: U.S. Federal Reserve, Bank of England, large-scale asset purchases, high-frequency data.

\footnotetext{
Rosa: Federal Reserve Bank of New York (e-mail: carlo.rosa@ny.frb.org). For their useful comments, the author thanks seminar participants at the Federal Reserve Bank of New York (Markets and Research), especially Lisa Chung, Adriana Cristea, Bianca De Paoli, George Dotsis, Matt Raskin, Andrea Tambalotti, and Giovanni Verga. The author also thanks Ross Finley of the Reuters polling unit for providing the Thomson-Reuters survey expectations on the Bank of England's gilt purchases. The views expressed in this paper are those of the author and do not necessarily reflect the position of the Federal Reserve Bank of New York or the Federal Reserve System.
} 


\section{Introduction}

In 2008 the Fed contrasted the sharp downturn in domestic economic conditions by substantially cutting its policy rate, culminating on December 16, 2008 with a federal funds target rate set to a range of 025 basis points. Despite reaching the zero lower bound on its main operating instrument, the Fed needed to further ease monetary conditions as the economic outlook deteriorated. The Federal Open Market Committee (henceforth FOMC) tackled this challenge by implementing the Large-Scale Asset Purchases (LSAP) program. In a nutshell, the Fed purchased large volumes of assets, such as housing agency debt, agency mortgage-backed securities (MBS) and longer-term Treasury securities, thus increasing the level of central bank reserves. In the second part of 2010 the Fed implemented a second round of monetary stimulus (dubbed LSAP2) by both reinvesting principal payments from its securities holdings and carrying out new purchases in longer-term Treasury securities in order to jump-start the sluggish economic recovery and to avoid undershooting the inflation target. ${ }^{1}$ This paper examines the impact of the Fed's conventional and unconventional monetary policy measures on the U.S. asset prices (nominal and inflation-indexed bonds, stocks and U.S. dollar spot exchange rates) using an event study with intraday data. The impact of monetary policy on asset prices is an important topic for several reasons. From the perspective of monetary policy makers, understanding the link between monetary policy and asset prices is crucial to understand the policy transmission mechanism. From an asset pricing perspective, as evidenced by the extensive attention that the Federal Reserve receives in the financial press, market participants are obviously equally interested in estimating the response of asset prices to changes in monetary policy.

This paper contributes to the extant literature in three main aspects. First, consistent with the efficient market hypothesis that asset prices only react to new information, this work investigates the impact of the surprise component of LSAP announcements, rather than the mere presence of a LSAP statement. Moreover, the LSAP news is incorporated into a formal regression framework, thus controlling for the unanticipated policy rate decision and statement regarding the future policy path. By doing so, this econometric specification allows to explicitly control for the "signalling channel", i.e. LSAP announcements might affect asset prices because market participants learn about the underlying state of the economy and about how the central bank might react to these future developments. ${ }^{2}$ Second, this paper conducts a crosscountry comparison of the effectiveness of the LSAP, by also evaluating the experience of the U.K. The empirical evidence suggests that the impact of the Bank of England's (BoE) Quantitative Easing (QE)

\footnotetext{
${ }^{1}$ Gagnon, Raskin, Remache and Sack (2011) provides an excellent insider's description about how the first round of asset purchases were implemented.

${ }^{2}$ The other channel through which LSAP might affect asset prices is the portfolio rebalancing channel (Tobin, 1958, and Vayanos and Vila, 2009). According to this channel, investors do not view different financial assets as perfect substitutes. Hence, LSAP purchases reduce supply of long-term bonds, raising their prices and lowering their yields, and passing through to other asset prices.
} 
program on U.K. asset prices has been similar to that found in the United States. Third, this paper uses highfrequency data to examine the response of asset prices to conventional and unconventional monetary policy. There are several reasons why tick-by-tick event-study analysis is more appropriate than a lower-frequency (daily) study. First, by employing a narrow 30-min window surrounding the monetary policy announcements, I perform the closest thing to a natural experiment in macroeconomics, and thus I can isolate the effects of monetary policy on asset prices. Second, high-frequency data surmount the endogeneity-reverse causality problem that is pervasive with lower-frequency data. Finally, in a short enough window around the announcement, the monetary news should be the only information hitting the market. For this reason, the regression residual errors are smaller, and the precision of the point estimates is greatly enhanced, compared to those obtained by a low-frequency regression model. This issue is particularly relevant in a high-volatility state, such as during the recent financial crisis.

The main findings of the paper can be summarized as follows. First, I identify the surprise component of LSAP announcements by reading a number of Financial Times (FT) articles written before and after each FOMC meeting. Then, I document economically important effects of asset purchases on U.S. asset prices. I find that in a narrow window around the FOMC meeting the cumulative financial market impact of the unanticipated announcement of asset purchases in terms of their federal funds-rate-equivalent, i.e. change in the funds rate that would have the same financial market impact as a given quantity of asset purchases, is substantial, ranging between 0 (for 3-month yields) and 197 basis points (for 10-year yields), with the response of stock prices and foreign exchanges lying in this interval. These point estimates are, however, surrounded by considerable uncertainty. I also investigate the extent to which the effects of asset purchases are different compared to standard changes in the fed funds target rate. By looking at the crossasset reactions, this work concludes that the effects of asset purchases are not statistically different from an unanticipated cut in the fed funds target rate. Hence, this evidence suggests that LSAP is simply another tool to provide stimulus to the economy when the policy rate is stuck at the zero-lower bound. Second, the robustness of these findings is examined along several dimensions. For instance, I consider different estimators, such as members of the class of generalized empirical likelihood (GEL) estimators, and a different identification of the target and news shock. This sensitivity analysis corroborates the core finding that the Fed's LSAP were extremely successful in bringing down long-term yields, boosting stock prices, and reducing the value of the U.S. dollar when the policy rate reached the zero lower bound. Third, I find that the cumulative effects of asset purchases conducted by the Bank of England's Monetary Policy Committee (MPC) resulted in a reduction of long-term yields and an average depreciation of the British pound of about $2 \%$. Hence, the response of U.K. asset prices (except for stock prices) is broadly in line with the reaction of U.S. asset prices to the Fed's asset purchases. By looking at the cross-asset reactions, the effects of gilt purchases are not statistically different from an unanticipated cut in the BoE policy rate for 10- 
year gilts and exchange rates, whereas the impact of purchases on 5-year gilts and especially FTSE 100 stock index is significantly smaller.

By looking at the asset price reactions to the Federal Reserve's monetary policy, this paper is related to different strands of the literature. A number of studies investigate the influence of the Fed's unanticipated policy rate decisions on U.S. asset prices. For instance, Kuttner (2001) estimates the impact of monetary policy actions on Treasury-bill, note, and bond yields, and finds that interest rates' response to anticipated target rate changes is small, while their response to unanticipated changes is large and highly significant. Beechey and Wright (2009) look at the response of nominal and index-linked bond yields to macroeconomic and monetary news announcements. They find that yields jumped up on the stronger-than-expected data and down on the weaker-than-expected data, with the reactions complete within 10-min. Bernanke and Kuttner (2005) analyze the impact of changes in monetary policy on equity prices, and document that, on average, a hypothetical unanticipated 25-basis-point cut in the Federal funds rate target is associated with about a 1\% increase in broad stock indexes. Andersen, Bollerslev, Diebold and Vega (2003) and Faust, Rogers, Wang and Wright (2007) examine the intraday response of the U.S. spot exchange rate to real-time U.S. monetary and macroeconomic news. In particular, they find that that surprise changes in the federal funds target rate produce conditional mean jumps, and conclude that exchange-rate dynamics are linked to fundamentals. All in all, this strand of research has reached a consensus that U.S. asset prices respond strongly to unanticipated fed funds target rate decisions.

The financial market impact of central bank communication, as opposed to monetary policy actions, has recently received increasing attention in the academic literature, both theoretically and empirically (see Blinder, Ehrmann, Fratzscher, De Haan and Jansen, 2008, for an excellent survey). Rosa (2011a and 2011b) examines the effects of FOMC's decisions and statements on the level and volatility of U.S. stock and volatility indices, and the U.S. dollar exchange rates using an intraday event-study analysis. He finds that both policy decisions and communication have economically large and highly significant effects on stock prices and exchange rates, with the surprise component of statements accounting for most of the explainable variation in asset returns in response to monetary policy. This work shares the finding that FOMC news have a significant impact on U.S. asset returns (in the aftermath of announcements), and goes one step further by showing that the surprise component of LSAP announcements, as opposed to the surprise component of its policy decisions and statements, greatly adds to our understanding of the response of asset prices to monetary policy. Moreover, the present paper extends the sample period up to June 2011, thus covering the financial turbulence that started in August 2007. This exercise is interesting because it assesses the effectiveness of the monetary transmission mechanism in periods of heightened financial stress.

A final area of the rapidly growing empirical literature is on the financial market impact of the LSAP program. Table 1 summarizes some of the choices researchers have made with respect to the data and 
estimation method used, and reports their main findings. Overall, the empirical evidence supports the conclusion that LSAP reduce U.S. long-term interest rates.

Table 1 here

The rest of the paper is organized as follows. Section 2 describes the dataset. Section 3 contains the discussion of the empirical results of the U.S. asset price reactions to the Fed's monetary policy. Section 4 briefly examines the experience of the Bank of England with quantitative easing. Finally, Section 5 concludes. Appendix A provides the coding of the tone of FOMC statements together with the time stamp of their releases, and the data about LSAP surprises as well as quotations motivating the assigned value. Appendix B outlines the data cleaning procedure used to delete from ultra-high-frequency time series observations that do not reflect the market activity.

\section{Data}

\subsection{Asset price data}

The high-frequency dataset on U.S. asset prices includes nominal and inflation-indexed bonds, stocks and U.S. dollar spot exchange rates, and covers the period May 1999 - June 2011.

I consider 5-min quotes of yields to maturity on the most recently issued "on-the-run" 3- and 6month, 2-, 5- and 10-year nominal Treasury notes, and 5- and 10-year Treasury Inflation Protected Securities (TIPS). The stock market data consists of the 5-min observations on the Standard \& Poor's 500 cash index, whereas the exchange rate data consist of the 5-min observations for the U.S. dollar versus the euro (EUR), the Canadian dollar (CAD), the British pound (GBP), the Swiss franc (CHF), and the Japanese yen (JPY). For the analysis of the BoE I consider the 5-min yields on the 5- and 10-year U.K. government bonds (gilts), and prices on the FTSE 100 stock index and spot exchange rate of the British pound against the USD, EUR, CAD, CHF, and JPY. Midpoints of bid/ask quotes, observed at the end of each 5-min interval, are used to generate the series of (equally-spaced) 5-min continuously compounded exchange rate returns. For instance, the 10:00 observation in a given day stands for the last quotation from within the interval 9:55:00-9:59:59. The data for each day are stacked in serial order, but only the asset price returns in a thirty-minute window bracketing every FOMC announcement are used in the econometric analysis. ${ }^{3}$ If no trade occurs in a given 5min interval, I use the price from the previous interval, as long as the previous price is quoted within the last twenty minutes. Throughout this paper, I measure exchange rates in units of the domestic currency needed to buy one unit of the foreign currency, so that a negative change implies an appreciation of the U.S. dollar.

\footnotetext{
${ }^{3}$ Andersen, Bollerslev, Diebold and Vega (2003) and Bandi and Russell (2008) argue that 5-min returns provide a reasonable balance between sampling too frequently (and confounding price reactions with market microstructure noise, such as the bid-ask bounce, staleness, price discreteness, and the clustering of quotes), and sampling too infrequently (and blurring price reactions to news).
} 


\subsection{Monetary news}

The news data consist of the surprise component of both central bank words and deeds: the surprise change to the current federal funds target rate, and the surprise component of FOMC's statements (meant to capture revisions to the path of the future target federal funds rate).

Following Kuttner (2001), in this paper the surprise component of the FOMC's decision, the target shock (TS), is defined as the (appropriately scaled) change in the current month federal funds futures rate in a narrow window around FOMC announcements (spanning from 5-min prior to 25-min after the policy announcement).

As pointed out by Gurkaynak, Sack and Swanson (2005) and Rosa (2011a, 2011b), since May 1999 the FOMC has accompanied its federal funds target rate decisions by press statements regarding the likely direction of future monetary policy. For instance, the FOMC shares its views on the economic outlook by indicating whether the FOMC believes that the risks for the economy in the foreseeable future are weighted toward "conditions that may generate heightened inflation pressures" (hawkish statement), or "the risks are balanced" (neutral announcement), or "risks are weighted toward economic weakness" (dovish statement). To take adequately into account this forward-looking information, I consider the unexpected component of Fed communication, the news shock $(N S)$, which consists of the difference between what the FOMC declares and what the market expects the FOMC to declare. Following the methodology developed in Rosa (2011a, 2011b), I proceed in three steps. First, I apply a narrative approach (see Romer and Romer, 1989 and 2004), and I code on a numerical scale the tone of the FOMC statement regarding the future direction of its monetary policy (Table A1 in the Appendix reports the corresponding values associated with each FOMC press statements from May 1999 to June 2011). Second, I compute market participants' expectations of the Fed's announcement. Unfortunately, there are no direct measures concerning market expectations about the tone of the FOMC statement. Hence, in the spirit of the older literature (e.g. Barro, 1978), I have to rely on an econometric model to estimate the anticipated Fed's communication. More specifically, I follow Rosa (2011a) and I employ a forecasting regression that includes the Fed's previous statement, macroeconomic fundamentals (i.e. inflation and output growth), and the slope of the short-term yield curve measured 5-min before the release of the statement to predict future central bank announcements (further details about the construction of the $N S$ variable are provided in a supplemental Appendix available from the author). Finally, I compute the surprise component of central bank statements, the news shock.

\subsection{LSAP surprises}

This paper contributes to the existing literature on the financial market impact of LSAP by identifying the unanticipated component of LSAP announcements. Since traders are unlikely to respond to LSAP decisions that are already anticipated, it is crucially important to distinguish between expected and unexpected LSAP declarations to properly estimate the impact of unconventional monetary policy on asset 
prices. In the spirit of the older literature that relied on newspaper articles to measure target shocks (see the seminal work by Cook and Hahn, 1989), I proceed in two steps. ${ }^{4}$ First, I search the online version of the Financial Times (FT) newspaper (available at www.ft.com) to create a database of those articles that a) contain the keywords "Bernanke" or "FOMC", and b) are published in a narrow window (from one day before to one day after) the FOMC meeting that features a LSAP statement. A total of 87 articles were extracted. Second, I construct the LSAP shock, $L S A P S_{t}$, i.e. a surprise indicator of asset purchases. More specifically, I classify the LSAP announcements into those that give an inclination of more accommodative versus no change or tighter unconventional monetary policy:

\section{LSAPS $_{t}=\left\{\begin{array}{cc}+1 & \text { LSAP announcement more restrictive than expected } \\ 0 & \text { No surprise in LSAP announcement } \\ -1 & \text { LSAP announcement more expansionary than expected }\end{array}\right.$}

Table A2 in the Appendix illustrates the construction of the variable $L S A P S_{t}$ with a few examples based on the FT's commentaries. It is important to stress that the classification of LSAP news is based on my own judgment and does not rule out a possible wrong classification. To reduce the chance of potential misclassification, and in line with the work in content analysis, two other persons have coded the FT's stories independently, producing the same ranking of surprises.

Four additional caveats of the methodology should be emphasized. First, the ternary dummy $L S A P S_{t}$ represents a coarse measure of the LSAP surprise. In particular, it measures the direction of the news, but cannot capture its magnitude. In other words, the explanatory variable contains a measurement error, and the likely consequence is an underestimate of the LSAP coefficient, known as attenuation bias. Hence, the reported point estimates of the LSAP coefficient should be interpreted as a lower-bound of the consistent estimate of the effectiveness of LSAP. Second, a related point is that due to the limited sample of LSAP announcements, it is impossible to further decompose the LSAP news into a timing surprise (i.e. advancement or postponement of a more-or-less inevitable asset purchase) and a level surprise about the expected path of LSAP. Moreover, I cannot disentangle the extent to which different maturities and types of unanticipated bond purchases, such as purchases of housing agency debt, MBS and longer-term Treasury securities, affect asset prices. Third, the LSAP surprise can be nonzero even when there was no LSAP decision as long as market participants placed at least some probability on there being a purchase announcement. If this type of LSAP news is orthogonal to asset returns, the exclusion of these observations should not affect the consistency of the econometric estimates. However, this sample selection reduces the efficiency of the estimates, and thus works against finding any significance influence of LSAP purchases on driving U.S. asset prices. A final drawback of relying on newspapers articles to determine which statements were surprises is that the journalists' interpretation of the FOMC event may have been influenced,

\footnotetext{
${ }^{4}$ Some recent studies assessing the impact of financial news media on asset prices include Bernanke, Reinhart and Sack (2004), Ellingsen and Soderstrom (2004), Tetlock (2007) and Loughran and McDonald (2011).
} 
consciously or unconsciously, by the observed asset price responses. To cope with this hindsight bias, I follow Bernanke, Reinhart and Sack (2004) strategy, and I also used FT's commentaries written before each meeting to define the surprise component of LSAP announcements.

To sum up, monetary policy surprises are divided into three categories. A target shock is defined as the unexpected change in the federal funds target rate. A news shock measures the degree to which traders have revised the future expected monetary policy path following the release of the monetary policy statements. A LSAP shock measures the surprise component of asset purchase announcements. Table 2 presents a selection of descriptive statistics for all the variables used in this paper.

Table 2 here

\section{The response of the U.S. asset prices to monetary policy}

\subsection{Baseline estimation results}

What is the impact of the Fed's conventional and unconventional monetary policy on the U.S. asset prices? To answer this, I estimate the following baseline regression model separately for each asset price using only FOMC meeting days:

$R_{t}=\beta_{0}+\beta_{T S} T S_{t}+\beta_{N S} N S_{t}+\beta_{L S A P S} L S A P S_{t}+\varepsilon_{t}$

where $R_{t}$ is the asset price return in the 30 -min window surrounding the release of the FOMC statement (from 5-min before to 25-min after the event). The error term $\varepsilon_{t}$ represents other factors that affect asset prices on event times. These factors are assumed to be orthogonal to the explanatory variables of the regression. The novel aspect of Equation (2) is that it investigates whether unanticipated LSAP statements affects U.S. asset prices, after controlling for the surprise component of the Fed's target rate decision and news about its future policy tilt.

Table 3 reports the estimation results for each U.S. asset price. Each regression is estimated using ordinary least squares (OLS) with White-t statistics (White, 1980) to account for heteroskedasticity in the residuals. ${ }^{5}$ Rather than commenting on each regression individually, in the interest of brevity I summarize the most interesting aspects of the empirical results. The sign of the estimated coefficients on the target shock (TS) is, as expected, positive for nominal and inflation-indexed bond yields, and negative for stock and exchange rate returns. For instance, a one percentage point surprise tightening in the federal funds rate

\footnotetext{
${ }^{5}$ The regression in Equation (2) uses generated regressors. The statistical significance of the results is unchanged when bootstrapped (sampling-with-replacement bootstrap with 10,000 repetitions) standard errors are used (results available from the author upon request).
} 
causes a significant 55 (35) basis point increase on the 6-month (5-year) Treasury note yields, a 5.3\% drop in the SP 500 stock index, and a $2.7 \%$ appreciation of the EUR-USD exchange rate in the half-an-hour bracketing the event. These magnitudes are similar to those reported in previous studies, such as Kuttner (2001) for nominal bond yields (72 and 48 basis points effect on the 6-month and 5-year Treasury yields respectively, sample period June 1989 to February 2000), Bernanke and Kuttner (2005) for stock prices (4.7\% effect, sample period June 1989 through December 2002) and Rosa (2011a) for the U.S. dollar exchange rates (2.2\% appreciation of the EUR, sample period May 1999 to June 2007). Second, all U.S. asset prices, with the exception of the 3-month nominal and the 5-year TIPS yields, respond significantly to the unanticipated component of FOMC statements containing information regarding the future course of policy rates. This finding suggests that asset prices react to both FOMC decisions about the current fed funds target rate and statements about the future path of policy (see Gurkaynak, Sack and Swanson, 2005, for a similar conclusion). The most interesting aspect of Table 3 is, however, the estimates of the effects of the LSAP news on U.S. asset prices. As can be seen in the table, the coefficient of the LSAP shock is positive for bond yields, and negative for stock and exchange rate returns. For all asset prices, with the notable exception of short-term, the LSAP surprise is statistically significant. For the 10-year Treasury and TIPS yields the LSAPS coefficient is marginally insignificant at the $10 \%$ level. I find that an unanticipated dovish LSAP announcement is associated with a decline in the 5-year Treasury yields of roughly 9 basis points, a stock price increase of $0.9 \%$, and a depreciation of the U.S. dollar against major currencies of about $1 \%$. This magnitude is substantial, especially because it should be seen as a lower bound of the impact of asset purchases on U.S. asset prices. ${ }^{6}$ Furthermore, because of the unanticipated LSAP announcements long-term yields went down by a total of roughly $30-50$ basis points, stock prices increased by $3 \%$, and the value of the U.S. dollar fell by a total of roughly $3 \%$. All in all, this implies that according to the estimates reported in Table 3 the cumulative financial market impact of the LSAP program in terms of their federal funds-rateequivalent ranges between 0 (for 3-month Treasury yields) and 197 (for 10-year Treasury note) basis points, depending on the particular asset price. ${ }^{7}$ These ballpark figures square well with those reported by the N.Y. Fed President Dudley (2010), who suggests that " $\$ 500$ billion of purchases would provide about as much stimulus as a reduction in the federal funds rate of between half a point and three quarters of a point. But this estimate is sensitive to how long market participants expected the Fed to hold on to these assets", and the Chairman Bernanke (2011), according to whom "the second round of asset purchases probably lowered longer-term interest rates approximately 10 to 30 basis points (...) roughly equivalent in terms of its effect on the economy to a 40 to 120 basis point reduction in the federal funds rate."

\footnotetext{
${ }^{6}$ In the empirical exercise I consider only unanticipated LSAP announcements made on FOMC meeting days, rather than all LSAP announcements. In addition to stock effects, there are also flows effects as documented by D'Amico and King (2010).

${ }^{7}$ The cumulative stimulus of the LSAP program, expressed in federal funds rate-equivalent, is computed as $N \cdot \beta_{\text {LSAPS }} /$ $\beta_{T S}$, where $N$ is the sum of LSAP ternary dummies, and I multiply the ratio by 100 to express it in basis points. To assess the degree of uncertainty in this point estimate, I compute empirical confidence bands using simulations. More specifically, I take 10,000 draws from the joint distribution of $\left\{\beta_{T S}, \beta_{L S A P S}\right\}$, and compute the above proportion implied for each asset pair. Finally, I take the $2.5 \%$ and $97.5 \%$ percentiles.
} 
Finally, to shed further light on the economic importance of the effects of asset purchases on asset prices, I have compared the goodness of fit, as measured by the adjusted $\mathrm{R}^{2}$, of Equation (2) to two baseline specifications: the first one includes as explanatory variables only a constant and the target shock, whereas the second one includes a constant, the target and news shock. By including the surprise component of the FOMC statement, the adjusted $\mathrm{R}^{2}$ substantially increases. The novel feature of Table 3 , however, is the dramatic improvement in the fit once the LSAP shock is included in the regression specification. Hence, the effect of the LSAP shock is not only statistically different from zero and of the "expected" sign, but also quantitatively important. For instance, for the EUR exchange rate, the adjusted $\mathrm{R}^{2}$ statistics increases from $5 \%$ to $19 \%$ by including the news shock, and to $41 \%$ by further including the LSAP shock, whereas for the 10-year Treasury note the adjusted $\mathrm{R}^{2}$ increases from $10 \%$ to $29 \%$ by including the LSAP shock. Therefore, most of the explainable variation in U.S. asset prices in response to the Fed's monetary policy is due to unanticipated FOMC statements and announcements about future LSAP rather than to unexpected changes in the federal funds rate target.

Table 3 here

To examine the robustness of the above estimation results, and in line with some existing studies such as Gagnon, Raskin, Remache and Sack (2011), I extend the "baseline" event set to include the initial LSAP announcement on November 25, 2008, and the Chairman Bernanke's December 1, 2008 speech, where he stated that the Federal Reserve "could purchase longer-term Treasury securities (...) in substantial quantities." Estimation results (reported in a separate Appendix) show that stimulative asset purchases lower Treasury bond yields, boost stock prices and reduce the spot value of the U.S. dollar. Interestingly, the point estimates remain very close to those reported in Table 3.

\subsection{How unconventional are LSAP?}

The above findings raise the important question of how unconventional LSAP compare to standard changes in the fed funds target rate. In other words, to what extent asset purchases can be thought as a completely new instrument or as a more mundane monetary policy tool to circumvent the zero bound on the actual fed funds target rate? To further investigate this issue, I look at the magnitude of the impact of LSAP surprises relative to target shocks across different U.S. asset prices. In particular, I pool the sample across all U.S. asset prices, and I estimate this model by Seemingly Unrelated Regression (SUR) method to accounts for heteroskedasticity and contemporaneous correlation in the errors across equations. Then I test whether the effects of the LSAP program (in terms of their federal-funds-rate-equivalent) are the same across assets. The null hypothesis that the ratio between the LSAPS and TS coefficients is the same across assets is strongly rejected by the data ( $\mathrm{p}$-value equals 0.007 ). Hence, this evidence indicates that the financial market impact of 
asset purchases on U.S. asset prices is statistically different from the impact of unanticipated cut in the fed funds target rate.

To shed further light on how the effectiveness of LSAP compare to the normal pattern of conventional monetary policy, I consider all pair-wise combination of assets, and then I test whether the effects of the LSAP program in terms of their federal-funds-rate-equivalent are the same for that particular asset pair. More formally, I estimate by SUR method the following system of equations:

$\left\{\begin{array}{l}R_{t}^{(i)}=\beta_{0}^{(i)}+\beta_{T S}^{(i)} T S_{t}+\beta_{N S}^{(i)} N S_{t}+\beta_{L S A P S}^{(i)} L S A P S_{t}+\varepsilon_{t}^{(i)} \\ R_{t}^{(j)}=\beta_{0}^{(j)}+\beta_{T S}^{(j)} T S_{t}+\beta_{N S}^{(j)} N S_{t}+\beta_{L S A P S}^{(j)} L_{S A P S}+\varepsilon_{t}^{(j)}\end{array}\right.$

where $R_{t}^{(i)}$ is the return on asset $i$, and the rest of the notation is the same as above. Then I test the null hypothesis $H_{0}: \frac{\beta_{L S A P S}^{(i)}}{\beta_{T S}^{(i)}}=\frac{\beta_{L S A P S}^{(j)}}{\beta_{T S}^{(j)}}$. Table 4 reports the Wald test $\left(\chi^{2}\right.$ statistic $)$ for each asset pair. For most combinations the null hypothesis that the effects of unanticipated asset purchases, in terms of their federalfunds-rate-equivalent, are not statistically different from each other cannot be rejected at standard confidence levels. The only exceptions are represented by short-term interest rates (3- and 6-month Treasury bills and 2year Treasury notes), which do not significantly react to asset purchases, compared to 5-year nominal or inflation-indexed bonds, stock prices, and exchange rates, which do react. To a lesser extent, also U.S. stock prices respond significantly less to LSAP shocks compared to exchange rates. These findings indicate that the mapping of LSAP in terms of federal-funds-rate-equivalent critically depends on the asset class considered. Thus, the effectiveness of LSAP may be understated / overstated depending on the particular asset class that has been used to compute the mapping of LSAP in terms of their federal-funds-rateequivalent. Finally, note that by considering all asset prices (except short-term yields) the null hypothesis that the ratio between the LSAPS and TS coefficients is the same across assets cannot be rejected at standard confidence levels (the p-value equals 0.355).

Table 4 here

\subsection{Robustness checks}

I examine the robustness of the baseline estimation results of Section 3.1 along several dimensions: (i) I consider different estimators belonging to the class of generalized empirical likelihood (GEL) estimators. (ii) I use a different identification strategy of the monetary policy and news shock. (iii) I analyze the longer-term response of asset prices to monetary policy. I show that the main results of Section 3.1 are fairly robust. Thus this sensitivity analysis corroborates the core finding that LSAP news are a key driver of U.S. asset returns. In the interest of space, most of these results can be found in a supplemental Appendix. 
First, I employ three special cases of the GEL class, such as Empirical Likelihood (EL, also known as Nonparametric Maximum Likelihood Estimator), Exponential Tilting (ET), and Continuously Updating Estimator (CUE), to estimate the baseline specification of Equation (2). The GEL estimators are particularly well-suited to estimate the response of asset prices to news because they have better higher order asymptotic and small sample properties compared to the OLS estimator, and are robust to influential observations. Table 5 reports the estimation results (see Rosa, 2011a, Appendix B, for the computational details of the GEL estimators). Importantly, all the results continue to hold. The coefficient of the target, news and LSAP shocks are positive for bond yields and negative for stock and exchange rate returns, and remain highly statistically and economically significant for all asset prices. Moreover, the magnitudes of all regression coefficients are in line with the baseline results of Table 3, suggesting that the OLS procedure produces reliable point estimates and inferential results.

Table 5 here

Second, following the same methodology developed by Gurkaynak, Sack and Swanson (2005), I use intraday changes in money market forward rates in a 30-min window surrounding the FOMC announcements to extract indicators of monetary policy news without relying on subjective wording indicators. Despite using a completely different identification strategy of the news shock, all the results of Table 3 continue to hold: both the Target and the Path factors are statistically significant and economically relevant regressors to explain the impact of monetary policy surprises on U.S. asset prices. ${ }^{8}$ Furthermore, the Fed's unanticipated LSAP announcements are a key driver of the U.S. asset prices on FOMC meeting days.

Finally, central bankers are more interested in the longer-term impact of monetary policy to asset prices, rather than their initial reaction. To address this issue and evaluate the robustness of the intraday results of Table 3, I estimate the following equation:

$R_{t+k}=\beta_{0}^{(k)}+\beta_{T S}^{(k)} T S_{t}+\beta_{N S}^{(k)} N S_{t}+\beta_{L S A P S}^{(k)} L S A P S_{t}+\varepsilon_{t}^{(k)} \quad k=1, \ldots, 10$.

where $R_{t+k}$ is the asset price return from day $t$ to day $t+k$, and the rest of the notation is the same as in Equation (2). Figure 1 displays the point estimates (solid line) of the $\beta_{T S}^{(k)}, \beta_{N S}^{(k)}$, and $\beta_{L S A P S}^{(k)}$ up to ten days after the FOMC announcement together with two standard error bands (shaded area). Rather than commenting on each plot individually, in the interest of brevity I summarize the most interesting aspects of the empirical results. First, the effect of LSAP news is not statistically different from zero at the $5 \%$ level for most one-day asset returns (the case of $k=1$ ). This finding suggests that intraday asset price data provide

\footnotetext{
${ }^{8}$ The Target factor corresponds to surprise changes in the current federal funds rate target, and the Path factor corresponds to changes in futures rates out to horizons of one year that are independent of changes in the current funds rate target, and can be interpreted as a "future path of policy" factor.
} 
more precise point estimates of announcement effects compared to lower frequency (daily) data. Hence, the recent availability of new intraday datasets provides a rich source of information for conducting fruitful research in economics and finance. Second, the impact of all types of monetary news is fairly persistent over time, thus confirming that asset returns are martingales.

Figure 1 here

\section{The impact of the BoE QE on U.K. asset prices}

The Bank of England has also implemented a QE program in an effort to ease its monetary policy stance, stoke inflation and inflation expectations and spur economic growth, at times when its policy rate was close to zero. The BoE gilt purchases is equivalent to $14 \%$ of U.K. nominal GDP, and although it is smaller in absolute size, its scale is similar to that of the Federal Reserve LSAP, roughly 12 percent of 2009 nominal GDP for LSAP1 (Gagnon, Ramache, Raskin and Sack, 2011, p. 30) and about 4\% of U.S. GDP for LSAP2 (Swanson, 2011, p. 156). In contrast to the Fed, the BoE adopted a more incremental approach by upsizing the total amount of purchases over time on a meeting-by-meeting basis. The BoE Monetary Policy Committee (MPC) originally announced plans to purchase $£ 75$ billion in assets (March 5, 2009), and later expanded it to reach $£ 125$ billion (May 7, 2009), £175 billion (August 6, 2009), and finally $£ 200$ billion (November 5, 2009) before finally halting it in February 2010. The Federal Reserve increased the size of its balance sheet by outright asset purchases, whereas in U.K. gilt purchases have been undertaken by a subsidiary of the BoE - the Asset Purchase Facility Fund, and the potential losses of the QE program are covered by the H.M. Government. The type of asset purchased also varies by country: the Fed purchased housing agency debt, MBS and longer-term Treasury securities, while the BoE purchased overwhelmingly gilts. ${ }^{9}$

To assess the effectiveness of the BoE gilt purchases on U.K. asset prices, I use a high-frequency event-study analysis. More formally, I estimate the following baseline regression model separately for each asset price using only MPC meeting days:

$R_{t}=\beta_{0}+\beta_{T S} T S_{t}^{B o E}+\beta_{Q E S} Q E S_{t}^{B o E}+\varepsilon_{t}$

where $R_{t}$ stands for the change in nominal gilts, the FTSE 100 stock price return or the change in the natural logarithm of the British pound exchange rate from 5-min before the news release to 25-min after the event. The surprise component of the BoE's target decision, $T S_{t}^{B O E}$, is derived from the change on the 3-month

\footnotetext{
${ }^{9}$ The foreign holding of U.S. Treasury securities is roughly $50 \%$, whereas in the U.K. is about $34 \%$. These figures may indicate that the portfolio rebalancing channel may work differently in these two countries.
} 
Sterling futures (quoted on the Euronext exchange) in a narrow window around BoE announcements (spanning from 5-min prior to 25-min after the policy announcement). As argued by Joyce, Relleen and Sorensen (2008), the nearest futures contract to expire is well-suited to measure target shocks because the underlying 3-month Libor rate tracks closely the policy rate, and thus moves in this narrow window only to the extent that there is a policy surprise. Moreover, since the underlying asset is the 3-month interest rate at the time the futures contract expires, this measure of target shocks picks up mostly surprises to the level of the interest rate expected over the coming three months, rather than timing shocks. ${ }^{10} \mathrm{With}$ regard to the measurement of the surprise component of the Bank of England's QE statements, $Q E S_{t}^{B o E}$, I apply the same procedure outlined in Section 2.3. The only difference is that I look for those FT articles that contain the keyword "Bank of England", and I extract a total of 71 articles. Table A3 in the Appendix illustrates the construction of the variable $Q E S_{t}^{B O E}$ for the case of the BoE. Finally, there is no news shock for the case of the Bank of England, since its MPC does not release any forward-looking policy inclination.

Table 6 (top panel) reports the estimation results of the effects of the BoE interest rate and QE announcements on 5- and 10-year gilts, the FTSE 100 and the British pound exchange rate returns for the sample January 1999 - June 2011, excluding the extraordinary unscheduled meeting of September 18, 2001. The coefficient of the target shock is as expected positive for nominal yields, and negative for stock prices and exchange rates, though not always significantly different from zero. Following Bernanke and Kuttner (2005), I check whether there exist observations that have an unduly large effect on the regression estimates. The MPC meeting held on November 6, 2008, when the BoE policy rate was cut by 150 basis points, is associated with an influence statistic of about 2 (by far, the largest value of the whole sample). ${ }^{11}$ To assess the sensitivity of the results, I also estimate Equation (5) by dropping this observation. The bottom part of Table 6 indicates that the TS coefficient becomes larger, and strongly significant. On average, a hypothetical unanticipated 25-basis-point increase in the BoE policy rate implies a significant rise in 5-year nominal yields of 5 basis points, a decline in U.K. stock prices of roughly $2 \%$, and an appreciation of the pound sterling of $0.5 \%$ in the half-an-hour bracketing the event. This magnitude is similar to those reported in previous studies, such as Bredin, Hyde, Nitzsche and O'Reilly (2007), who estimate a $0.8 \%$ effect over the period January 1993 to May 2004 for the FTSE 100 stock index, and Kearns and Manners (2006), who finds a $0.4 \%$ effect over the period July 1997 to June 2004 for the USD-GBP exchange rate. The novel aspect of Table 6 is, however, the estimates of the QE impact. The coefficient of the QE shock is, as expected, positive

\footnotetext{
${ }^{10}$ As a sensitivity test, I also use survey data to construct an alternative measure of target shocks. In particular, I define the surprise component of the BoE's decision as the difference between the actual policy rate and the market participants' mean expectation taken from a Bloomberg survey of market economists (see Melvin, Saborowski, Sager and Taylor, 2010, for further details). The empirical findings (available from the author) are robust to this redefinition of the target shock variable.

${ }^{11}$ The influence statistics is defined as $\Delta \hat{\beta}_{t}{ }^{\prime} \hat{\Sigma}^{-1} \Delta \hat{\beta}_{t}$, where $\Delta \hat{\beta}_{t}$ represents the change in the vector of regression coefficients, in this case $\left\{\beta_{0}, \beta_{T S}, \beta_{Q E S}\right\}$, resulting from dropping observation $t$, and $\hat{\Sigma}^{-1}$ stands for the inverse of the estimated covariance matrix of the coefficients.
} 
for gilts, and marginally insignificant for the 10-year yields (p-value equals 10.2\%). The impact of asset purchases on the British pound exchange rate is negative, and always significantly different from zero at the 1\% level. More specifically, I find that an unanticipated dovish QE announcement of asset purchases, when the market expects no QE statement, is associated with a depreciation of the spot value of the British pound against major currencies of about $0.4 \%$. Overall, the response of U.K. asset prices is broadly in line with the reaction of U.S. asset prices to the Fed's asset purchases. The only exception to this broad pattern is represented by stock prices that somewhat surprisingly do not react to QE shocks. According to the estimates reported in Table 6 the cumulative impact of the QE program in a narrow window around monetary policy announcements is equivalent to an unanticipated cut in the BoE policy rate of about -16-273 basis points (-16-146 basis points in the bottom table). This magnitude is quantitatively similar to response of U.S. asset prices to LSAP news, estimated to be equivalent to a 0-197 basis points shock to the fed funds target rate. Similar to the U.S., the economic importance of the effects of gilt purchases on asset prices is substantial. For instance, by including the surprise component of QE, the adjusted $\mathrm{R}^{2}$ increases from $12 \%$ to $28 \%$ for the 10 -year gilts, and from $24 \%$ to $38 \%$ for the USD-GBP exchange rate.

Table 6 here

To assess how gilt purchases compare to changes in the BoE target rate, I test whether the effects of the QE program in terms of their policy-rate-equivalent are the same across assets. Table 7 reports the Wald test $\left(\chi^{2}\right.$ statistic) for each asset pair. In the interest of brevity I summarize the most interesting aspects of the empirical results. For all exchange rates and 10-year yields, the null hypothesis that the effects of unanticipated gilt purchases in terms of their policy-rate-equivalent are not statistically different from each other cannot be rejected at standard confidence levels. The response of stock prices to QE shocks is markedly different from all other asset prices. Finally, also 5-year yields respond significantly less to QE shocks compared to 10 -year yields.

Table 7 here

The above results are quite robust to changes in the identification strategy of the QE surprises. More specifically, I define $Q E S_{t}^{B O E}$ as the difference between the actual value of gilt purchases announced and market participants' prior expectation of what that value would be. I measure the expected gilt figure using the average survey expectation from Reuters. ${ }^{12}$ Importantly, estimation results (available upon request)

\footnotetext{
${ }^{12}$ Unfortunately, there was no question in the Reuters poll on expected gilt purchases before April 2009. Hence, to compute QES for the February and March 2009 announcements, I follow Joyce, Lasaosa, Stevens and Tong (2011. p. 136) and distribute equally the Reuters April 2009 survey between the February and March announcement dates. Note that this is a conservative assumption since as long as QE was in part anticipated, the amount of news is overstated and hence the response of U.K. asset prices to QES underestimated.
} 
confirm that the general message of the paper (i.e., sign and significance of the $Q E S_{t}^{B O E}$ coefficient) survives this sensitivity exercise. It is also reassuring to find that the cumulative financial market impact of gilt purchases on the British pound exchange rate corresponds to an unanticipated cut in the BoE's policy rate that ranges between -3 and 217 basis points when considering the full sample, and between 0 and 184 when considering the sample that excludes the November 2008 meeting.

\section{Conclusions}

The goal of this paper is to deepen our understanding of the links between monetary policy and asset prices. In contrast to the existing literature, I investigate the impact of the surprise component of LSAP announcements, rather than the mere presence of an LSAP statement. This is an important methodological advance since according to the efficient market hypothesis asset prices only react to new information. I carry out the econometric analysis in two steps. First, I identify the surprise component of LSAP announcements from Financial Times articles. Then, I incorporate the LSAP news into a formal regression framework, thus controlling for the unanticipated target rate decision and statement regarding the future policy path. Estimation results document economically large effects of the Fed's asset purchases on U.S. asset prices, corresponding roughly to an unanticipated cut in the fed funds target rate that ranges between 0 (for 3-month yields) and 197 basis points (for 10-year yields). These point estimates are, however, surrounded by considerable uncertainty. By looking at the cross-asset reactions, this work concludes that for most asset prices the effects of asset purchases are not statistically different in the U.S. from an unanticipated cut in the target rate. This study also shows that the response of U.K. asset prices to the Bank of England's gilt purchases has been quantitatively similar to the reaction of U.S. asset prices to the Fed's LSAP program.

The findings of this paper have important policy implications. In particular, this work precisely quantifies the effects of the Fed's LSAP shocks on the U.S. asset prices, and thus it sheds more light on the link between monetary policy and asset prices, and ultimately on the policy transmission mechanism. Building on the results of this paper, a key direction for future research would be to investigate the channels through which LSAP might help in achieving the Federal Reserve's goals of promoting price stability and maintaining long-run growth. For instance, has the creation of bank reserves increased bank lending? Or has LSAP boosted the confidence in the economic recovery? Furthermore, this study documents that unanticipated LSAP purchases strongly affect asset prices. However, are LSAP optimal? In other words, should central banks buy Treasury bonds to further ease monetary conditions when their policy rate hits the zero lower bound, or are the costs associated with this policy larger than the potential benefits? Unfortunately, in the absence of a microfounded DSGE model it is impossible to provide a definitive answer. 


\section{References}

Andersen, T.G., Bollerslev, T., Diebold, F., Vega, C., 2003. Micro effects of macro announcements: realtime price discovery in foreign exchange. American Economic Review 93 (1), 38-62.

Bandi, F., Russell, J.R., 2008. Microstructure noise, realized variance, and optimal sampling. Review of Economic Studies 75, 339-369.

Barndorff-Nielsen, O.E., Hansen, P., Lunde, A., Shephard, N., 2009. Realised kernels in practice: trades and quotes. Econometrics Journal 12, C1-C32.

Barro, R.J., 1978. Unanticipated money, output, and the price level in the United States. Journal of Political Economy 86 (4), 549-580.

Bauer, M.D., Rudebusch, G.D., 2011. The signaling channel for Federal Reserve bond purchases. Federal Reserve Bank of San Francisco Working Paper 2011-21.

Beechey, M.J., Wright, J.H., 2009. The high-frequency impact of news on long-term yields and forward rates: is it real? Journal of Monetary Economics 56, 535-544.

Bernanke, B.S., Reinhart, V., Sack, B., 2004. Monetary policy alternatives at the zero bound: an empirical assessment. Brookings Papers on Economic Activity 2, 1-100.

Bernanke, B., Kuttner, K., 2005. What explains the stock market's reaction to Federal Reserve policy? Journal of Finance 60 (3), 1221-1257.

Bernanke, B.S., 2011. Semiannual monetary policy report to the Congress before the committee on financial services. U.S. House of Representatives, Washington, D.C., July 13, 2011.

Blinder, A. S., Ehrmann, M., Fratzscher, M., De Haan, J., Jansen, J. 2008. Central bank communication and monetary policy: a survey of theory and evidence. Journal of Economic Literature 46 (4), 910-945.

Bredin, D., Hyde, S., Nitzsche, D., O'Reilly, G., 2007. UK stock returns and the impact of domestic monetary policy shocks. Journal of Business Finance and Accounting 34(5-6), 872-888.

Brownless, C.T., Gallo, G.M., 2006. Financial econometrics at ultra-high frequency: data handling concerns. Computational Statistics and Data Analysis 51, 2232-2245.

Cook, T., Hahn, T., 1989. The effect of changes in the Federal funds target on market interest rates in the 1970s. Journal of Monetary Economics 24, 331-351.

D'Amico, S., King, T., 2010. Flow and stock effects of large-scale treasury purchases. Finance and Economics Discussion Series Paper No. 2010-52, Board of Governors of the Federal Reserve System.

Dudley, W.C., 2010. The outlook, policy choices and our mandate. Remarks at the at the Society of American Business Editors and Writers Fall Conference, City University of New York, Graduate School of Journalism, New York City, October 1, 2010.

Ellingsen, T., Soderstrom, U., 2004. Why are long rates sensitive to monetary policy? CEPR Discussion Paper 4360.

Fatum, R., Scholnick, B., 2008. Monetary policy news and exchange rate responses: Do only surprises matter? Journal of Banking and Finance 32, 1076-1086. 
Faust, J., Rogers, J. H., Wang, S.-Y. B., Wright, J. H., 2007. The high-frequency response of exchange rates and interest rates to macroeconomic announcements. Journal of Monetary Economics 54, 1051-1068.

Fleming, M.J., Piazzesi, M., 2005. Monetary policy tick by tick. Unpublished paper, Federal Reserve Bank of New York, 2005.

Gagnon, J., Raskin, M., Remache, J., Sack, B., 2011. The financial market effects of the Federal Reserve's large-scale asset purchases. International Journal of Central Banking 7 (1), 3-43.

Gençay, R., Dacorogna, M., Muller, U.A., Pictet, O., Olsen, R., 2001. An introduction to high-frequency finance. Academic Press: California, United States.

Gurkaynak, R., Sack, B., Swanson, E., 2005. Do actions speak louder than words? The response of asset prices to monetary policy actions and statements. International Journal of Central Banking 1 (1), 55-93.

Hamilton, J., Wu, C., 2011. The effectiveness of alternative monetary policy tools in a zero lower bound environment. Journal of Money, Credit and Banking, forthcoming.

Hancock, D., Passmore, W., 2011. Did the Federal Reserve's MBS purchase program lower mortgage rates? Journal of Monetary Economics 58, 498-514.

Joyce, M., Relleen, J., Sorensen, S., 2008. Measuring monetary policy expectations from financial market instruments. Bank of England Working Paper 356.

Joyce, M., Lasaosa, A., Stevens, I., Tong, M., 2011. The financial market impact of quantitative easing in the United Kingdom. International Journal of Central Banking 7 (3), 113-161.

Kearns, J., Manners, P., 2006. The impact of monetary policy on the exchange rate: A study using intraday data. International Journal of Central Banking 2 (4), 157-183.

Krishnamurthy, A., Vissing-Jorgensen, A., 2011. The effects of quantitative easing on interest rates: channels and implications for policy. Working paper, Northwestern University.

Kuttner, K., 2001. Monetary policy surprises and interest rates: Evidence from the Fed Funds futures markets. Journal of Monetary Economics 47, 523-544.

Loughran, T., McDonald, B., 2011. When is a liability not a liability? Textual analysis, dictionaries, and 10Ks. Journal of Finance 66 (1), 35-65.

MacKinlay, A.C., 1997. Event studies in economics and finance. Journal of Economic Literature 35 (1), 1339.

Melvin, M., Saborowski, C., Sager, M., Taylord, M.P., 2010. Bank of England interest rate announcements and the foreign exchange market. International Journal of Central Banking 6 (3), 211-247.

Neely, C., 2010. The large-scale asset purchases had large international effects. Federal Reserve Bank of St. Louis Working Paper No. 2010-018A.

Rigobon, R., Sack, B.P., 2004. The impact of monetary policy on asset prices. Journal of Monetary Economics 51, 1553-1575.

Romer, C., Romer, D., 1989. Does monetary policy matter? A new test in the spirit of Friedman and Schwartz. NBER Macroeconomics Annual, 121-170. 
Romer, C., Romer, D., 2004. A new measure of monetary shocks: Derivation and implications. American Economic Review 94(4), 1055-1084.

Rosa, C., 2011a. Words that shake traders. Journal of Empirical Finance 18 (5), 915-934.

Rosa, C., 2011b. The high-frequency response of exchange rates to monetary policy actions and statements. Journal of Banking and Finance 35, 478-489.

Swanson, E.T., 2011. Let's twist again: a high-frequency event-study analysis of operation twist and its implications for LSAP2. Brookings Papers on Economic Activity, 151-188.

Tetlock, P.C., 2007, Giving content to investor sentiment: the role of media in the stock market. Journal of Finance 62, 1139-1168.

Tobin, J, 1958. Liquidity preferences as behavior towards risk. Review of Economic Studies 25, 124-131.

Vayanos, D., Vila, J.L., 2009. A preferred-habitat model of the term structure of interest rates. NBER Working Paper 15487.

White, H., 1980. A heteroskedasticity-consistent covariance matrix estimator and a direct test for heteroskedasticity. Econometrica 48 (4), 817-838.

Wright, J.H., 2011. What does monetary policy do to long-term interest rates at the zero lower bound? NBER Working Paper 17154. 


\section{Appendix A: Data}

\section{Table A1 \\ Coding of FOMC statements}

The table reports the tone of the FOMC statements (available at http://www.federalreserve.gov/boarddocs/press/all). The sample period is May 1999 - June 2011. The announcement times (EST) of the Fed's monetary policy decisions are obtained through searches of various media sources such as Bloomberg and Reuters (see, also, Gurkaynak, Sack and Swanson, 2005, Fleming and Piazzesi, 2005, and the letter by Carol R. Low of the FOMC FOIA Service Center dated November 23, 2010). Note that there are no time stamps available for the following (unscheduled) FOMC dates: December 6, 2007, January 9, 2008, July 24, 2008, September 29, 2008, January 16, 2009, February 7, 2009, and June 3, 2009 , because no statement was released as a consequence of these meetings. The tone of the FOMC statements released on August 10, 2007, and March 11, 2008 are not classified because no explicit balance-of-risk assessment is provided. On December 16, 2008 the variable $N S_{t}$ equals zero because the fed target rate hits the zero lower bound, and thus the surprise component of the statement cannot be hawkish. The variable Index ${ }_{t}^{O L D}$ on April 29, 2009 equals zero, rather than -1 , because the fed target rate is already at zero and cannot be further cut. The unscheduled FOMC meetings are highlighted in grey.

\begin{tabular}{|c|c|c|c|}
\hline Date & Time & Index & $\begin{array}{c}\text { New Fed } \\
\text { Funds Target } \\
\text { Rate } \\
\end{array}$ \\
\hline $05 / 18 / 1999$ & $2.11 \mathrm{PM}$ & 1 & 4.75 \\
\hline 06/30/1999 & $2.15 \mathrm{PM}$ & 0 & 5 \\
\hline 08/24/1999 & 2.14 PM & 0 & 5.25 \\
\hline 10/05/1999 & $2.12 \mathrm{PM}$ & 1 & 5.25 \\
\hline 11/16/1999 & $2.16 \mathrm{PM}$ & 0 & 5.5 \\
\hline $12 / 21 / 1999$ & $2.13 \mathrm{PM}$ & 0 & 5.5 \\
\hline $02 / 02 / 2000$ & 2.14 PM & 1 & 5.75 \\
\hline $03 / 21 / 2000$ & $2.15 \mathrm{PM}$ & 1 & 6 \\
\hline 05/16/2000 & 2.13 PM & 1 & 6.5 \\
\hline $06 / 28 / 2000$ & $2.15 \mathrm{PM}$ & 1 & 6.5 \\
\hline $10 / 03 / 2000$ & $2.12 \mathrm{PM}$ & 1 & 6.5 \\
\hline $08 / 22 / 2000$ & 2.15 PM & 1 & 6.5 \\
\hline $11 / 15 / 2000$ & $2.12 \mathrm{PM}$ & 1 & 6.5 \\
\hline $12 / 19 / 2000$ & $2.16 \mathrm{PM}$ & -1 & 6.5 \\
\hline 01/03/2001 & $1.13 \mathrm{PM}$ & -1 & 6.0 \\
\hline $01 / 31 / 2001$ & $2.15 \mathrm{PM}$ & -1 & 5.5 \\
\hline 03/20/2001 & $2.13 \mathrm{PM}$ & -1 & 5 \\
\hline $04 / 18 / 2001$ & $10.54 \mathrm{AM}$ & -1 & 4.5 \\
\hline 05/15/2001 & $2.15 \mathrm{PM}$ & -1 & 4 \\
\hline $06 / 27 / 2001$ & $2.12 \mathrm{PM}$ & -1 & 3.75 \\
\hline $08 / 21 / 2001$ & $2.13 \mathrm{PM}$ & -1 & 3.5 \\
\hline 09/17/2001 & 8.20 AM & -1 & 3 \\
\hline $10 / 02 / 2001$ & $2.15 \mathrm{PM}$ & -1 & 2.5 \\
\hline $11 / 06 / 2001$ & $2.20 \mathrm{PM}$ & -1 & 2 \\
\hline $12 / 11 / 2001$ & 2.14 PM & -1 & 1.75 \\
\hline 01/30/2002 & $2.16 \mathrm{PM}$ & -1 & 1.75 \\
\hline 03/19/2002 & 2.19 PM & 0 & 1.75 \\
\hline 05/07/2002 & $2.14 \mathrm{PM}$ & 0 & 1.75 \\
\hline $06 / 26 / 2002$ & $2.13 \mathrm{PM}$ & 0 & 1.75 \\
\hline 08/13/2002 & 2.14 PM & -1 & 1.75 \\
\hline 09/24/2002 & $2.12 \mathrm{PM}$ & -1 & 1.75 \\
\hline $11 / 06 / 2002$ & $2.14 \mathrm{PM}$ & 0 & 1.25 \\
\hline $12 / 10 / 2002$ & $2.13 \mathrm{PM}$ & 0 & 1.25 \\
\hline $01 / 29 / 2003$ & $2.16 \mathrm{PM}$ & 0 & 1.25 \\
\hline 03/18/2003 & $2.15 \mathrm{PM}$ & 0 & 1.25 \\
\hline 05/06/2003 & $2.13 \mathrm{PM}$ & -1 & 1.25 \\
\hline $06 / 25 / 2003$ & $2.16 \mathrm{PM}$ & -1 & 1 \\
\hline $08 / 12 / 2003$ & $2.15 \mathrm{PM}$ & 0 & 1 \\
\hline 09/16/2003 & $2.19 \mathrm{PM}$ & 0 & 1 \\
\hline
\end{tabular}

\begin{tabular}{|c|c|c|c|}
\hline Date & Time & Index & $\begin{array}{l}\text { New Fed Funds } \\
\text { Target Rate }\end{array}$ \\
\hline $08 / 09 / 2005$ & $2.17 \mathrm{PM}$ & 1 & 3.5 \\
\hline 09/20/2005 & $2.17 \mathrm{PM}$ & 1 & 3.75 \\
\hline $11 / 01 / 2005$ & $2.18 \mathrm{PM}$ & 1 & 4 \\
\hline $12 / 13 / 2005$ & $2.13 \mathrm{PM}$ & 1 & 4.25 \\
\hline $01 / 31 / 2006$ & $2.14 \mathrm{PM}$ & 1 & 4.5 \\
\hline 03/28/2006 & $2.17 \mathrm{PM}$ & 1 & 4.75 \\
\hline 05/10/2006 & 2.17 PM & 1 & 5 \\
\hline $06 / 29 / 2006$ & $2.16 \mathrm{PM}$ & 1 & 5.25 \\
\hline 08/08/2006 & $2.14 \mathrm{PM}$ & 0 & 5.25 \\
\hline 09/20/2006 & $2.14 \mathrm{PM}$ & 0 & 5.25 \\
\hline $10 / 25 / 2006$ & $2.13 \mathrm{PM}$ & 0 & 5.25 \\
\hline $12 / 12 / 2006$ & $2.14 \mathrm{PM}$ & 0 & 5.25 \\
\hline $01 / 31 / 2007$ & $2.14 \mathrm{PM}$ & 0 & 5.25 \\
\hline $03 / 21 / 2007$ & $2.15 \mathrm{PM}$ & 0 & 5.25 \\
\hline 05/09/2007 & $2.15 \mathrm{PM}$ & 0 & 5.25 \\
\hline $06 / 28 / 2007$ & $2.14 \mathrm{PM}$ & 0 & 5.25 \\
\hline 08/07/2007 & $2.14 \mathrm{PM}$ & 0 & 5.25 \\
\hline 08/10/2007 & $9.15 \mathrm{AM}$ & NA & 5.25 \\
\hline 08/17/2007 & 8.15 AM & -1 & 5.25 \\
\hline 09/18/2007 & 2:15 PM & 0 & 4.75 \\
\hline $10 / 31 / 2007$ & 2:15 PM & 0 & 4.5 \\
\hline $12 / 11 / 2007$ & $2.16 \mathrm{PM}$ & 0 & 4.25 \\
\hline $01 / 22 / 2008$ & $8.21 \mathrm{AM}$ & -1 & 3.5 \\
\hline 01/30/2008 & $2.14 \mathrm{PM}$ & -1 & 3 \\
\hline 03/11/2008 & $8.30 \mathrm{AM}$ & NA & 3 \\
\hline 03/18/2008 & $2.14 \mathrm{PM}$ & -1 & 2.25 \\
\hline $04 / 30 / 2008$ & $2.15 \mathrm{PM}$ & 0 & 2 \\
\hline $06 / 25 / 2008$ & $2.09 \mathrm{PM}$ & 0 & 2 \\
\hline $08 / 05 / 2008$ & $2.13 \mathrm{PM}$ & 0 & 2 \\
\hline 09/16/2008 & $2.14 \mathrm{PM}$ & 0 & 2 \\
\hline $10 / 08 / 2008$ & $7.00 \mathrm{AM}$ & -1 & 1.5 \\
\hline $10 / 29 / 2008$ & $2.17 \mathrm{PM}$ & -1 & 1 \\
\hline $12 / 16 / 2008$ & $2.21 \mathrm{PM}$ & 0 & $0-0.25$ \\
\hline 01/28/2009 & $2.15 \mathrm{PM}$ & 0 & $0-0.25$ \\
\hline 03/18/2009 & $2.17 \mathrm{PM}$ & -1 & $0-0.25$ \\
\hline 04/29/2009 & $2.16 \mathrm{PM}$ & 0 & $0-0.25$ \\
\hline 06/24/2009 & $2.18 \mathrm{PM}$ & 0 & $0-0.25$ \\
\hline $08 / 12 / 2009$ & $2.16 \mathrm{PM}$ & 0 & $0-0.25$ \\
\hline 09/23/2009 & $2.16 \mathrm{PM}$ & 0 & $0-0.25$ \\
\hline
\end{tabular}




\begin{tabular}{lllc}
$10 / 28 / 2003$ & $2.14 \mathrm{PM}$ & 0 & 1 \\
$12 / 09 / 2003$ & $2.14 \mathrm{PM}$ & 0 & 1 \\
$01 / 28 / 2004$ & $2.14 \mathrm{PM}$ & 1 & 1 \\
$03 / 16 / 2004$ & $2.15 \mathrm{PM}$ & 1 & 1 \\
$05 / 04 / 2004$ & $2.16 \mathrm{PM}$ & 1 & 1 \\
$06 / 30 / 2004$ & $2.18 \mathrm{PM}$ & 1 & 1.25 \\
$08 / 10 / 2004$ & $2.15 \mathrm{PM}$ & 1 & 1.5 \\
$09 / 21 / 2004$ & $2.15 \mathrm{PM}$ & 1 & 1.75 \\
$11 / 10 / 2004$ & $2.15 \mathrm{PM}$ & 1 & 2 \\
$12 / 14 / 2004$ & $2.16 \mathrm{PM}$ & 1 & 2.25 \\
$02 / 02 / 2005$ & $2.17 \mathrm{PM}$ & 1 & 2.5 \\
$03 / 22 / 2005$ & $2.17 \mathrm{PM}$ & 1 & 2.75 \\
$05 / 03 / 2005$ & $2.16 \mathrm{PM}$ & 1 & 3 \\
$06 / 30 / 2005$ & $2.15 \mathrm{PM}$ & 1 & 3.25 \\
\hline \hline
\end{tabular}

\begin{tabular}{llll}
$11 / 04 / 2009$ & $2.18 \mathrm{PM}$ & 0 & $0-0.25$ \\
$12 / 16 / 2009$ & $2.15 \mathrm{PM}$ & 0 & $0-0.25$ \\
$01 / 27 / 2010$ & $2.16 \mathrm{PM}$ & 0 & $0-0.25$ \\
$03 / 16 / 2010$ & $2.14 \mathrm{PM}$ & 0 & $0-0.25$ \\
$04 / 28 / 2010$ & $2.14 \mathrm{PM}$ & 0 & $0-0.25$ \\
$06 / 23 / 2010$ & $2.16 \mathrm{PM}$ & 0 & $0-0.25$ \\
$08 / 10 / 2010$ & $2.19 \mathrm{PM}$ & 0 & $0-0.25$ \\
$09 / 21 / 2010$ & $2.18 \mathrm{PM}$ & 0 & $0-0.25$ \\
$11 / 03 / 2010$ & $2.16 \mathrm{PM}$ & 0 & $0-0.25$ \\
$12 / 14 / 2010$ & $2.15 \mathrm{PM}$ & 0 & $0-0.25$ \\
$26 / 01 / 2011$ & $2.15 \mathrm{PM}$ & 0 & $0-0.25$ \\
$15 / 03 / 2011$ & $2.14 \mathrm{PM}$ & 0 & $0-0.25$ \\
$27 / 04 / 2011$ & $12.33 \mathrm{PM}$ & 0 & $0-0.25$ \\
$22 / 06 / 2011$ & $12.27 \mathrm{PM}$ & 0 & $0-0.25$ \\
\hline
\end{tabular}


Table A2

Examples of the Financial Times commentaries about the Fed's LSAP

The table reports selected excerpts of Financial Times commentaries about the Federal Reserve's LSAP announcements, together with the value of the signed dummy variable $L S A P S_{t}$.

\begin{tabular}{|c|c|c|}
\hline Date & FT commentaries & $L_{S A P S_{t}}$ \\
\hline $1 / 28 / 2009$ & $\begin{array}{l}\text { The Federal Reserve failed to exert serious downward pressure on yields this week as its } \\
\text { remarks that it was prepared to buy long-term Treasuries - if it would help improve } \\
\text { conditions in the credit markets - were seen as nothing new. }\end{array}$ & 0 \\
\hline $3 / 18 / 2009$ & $\begin{array}{l}\text { - The Federal Reserve yesterday stunned investors by announcing plans to buy } \$ 300 b n \text { of } \\
\text { US government debt, triggering a plunge in bond yields and the dollar. } \\
\text { - The plan to buy Treasuries caught investors off guard. "It appears that they wanted to give } \\
\text { the market a jolt," said Peter Hooper, an economist at Deutsche Bank. }\end{array}$ & -1 \\
\hline $8 / 12 / 2009$ & $\begin{array}{l}\text { There was no surprise on interest rates, and only minor technocratic tinkering with its plan to } \\
\text { buy Treasury bonds. }\end{array}$ & 0 \\
\hline $9 / 23 / 2009$ & $\begin{array}{l}\text { Pretty much as expected I think, including the three month extension of the agency } \\
\text { MBS/debt programme, with a few interesting vignettes. }\end{array}$ & 0 \\
\hline $11 / 4 / 2009$ & $\begin{array}{l}\text { The Federal Open Market Committee decided to shave } \$ 25 \mathrm{bn} \text { off the planned } \$ 200 \mathrm{bn} \text { purchase } \\
\text { of debt issued by Fannie Mae and Freddie Mac. The decision was justified on technical grounds } \\
\text { reflecting "the limited availability of agency debt". The reduction only makes the tiniest dent } \\
\text { in the Fed's overall } \$ \mathbf{1 , 7 5 0 b n} \text { asset purchase programme. }\end{array}$ & 0 \\
\hline $8 / 10 / 2010$ & $\begin{array}{l}\text { There was about a 50-50 chance that the Federal Reserve would take the course it chose } \\
\text { today with the decision to reinvest proceeds from expiring mortgage-backed securities. }\end{array}$ & -1 \\
\hline $9 / 21 / 2010$ & $\begin{array}{l}\text { - The statement issued by Fed policymakers on Tuesday, after the central bank left } \\
\text { interest rates unchanged, went further than many investors had expected. (...) That bias } \\
\text { towards monetary easing, absent from its last policy statement, triggered speculation that the } \\
\text { Fed would embark on another round of asset purchases to pump money into the economy. } \\
\text { - "The statement has been widely interpreted as paving the way for the next stage of } \\
\text { quantitative easing, with November being touted as the most likely date," said Gavan } \\
\text { Nolan, credit analyst at Markit. }\end{array}$ & -1 \\
\hline $11 / 3 / 2010$ & $\begin{array}{l}\text { - Leaving aside all question of whether LSAP } 2 \text { will "work" in the long-run, the Fed's short- } \\
\text { term execution has been a triumph. It managed to prepare market expectations so that } \\
\text { there were almost no dramatic price moves in response to a formidably complicated } \\
\text { policy. } \\
\text { - The central bank's announcement that it would purchase an additional } \$ 600 \mathrm{bn} \text { of longer } \\
\text { term Treasury securities by the middle of next year was broadly in line with market } \\
\text { expectations. } \\
\text { - The Fed ultimately has delivered something pretty close to central expectations. }\end{array}$ & 0 \\
\hline
\end{tabular}


Table A3

Examples of the Financial Times commentaries about the Bank of England's QE

The table reports selected excerpts of Financial Times commentaries about the Bank of England's QE announcements, together with the value of the signed dummy variable $Q E S_{t}^{B O E}$. The column "QE amount" stands for the MPC announcement of the total gilt purchases (in billions).

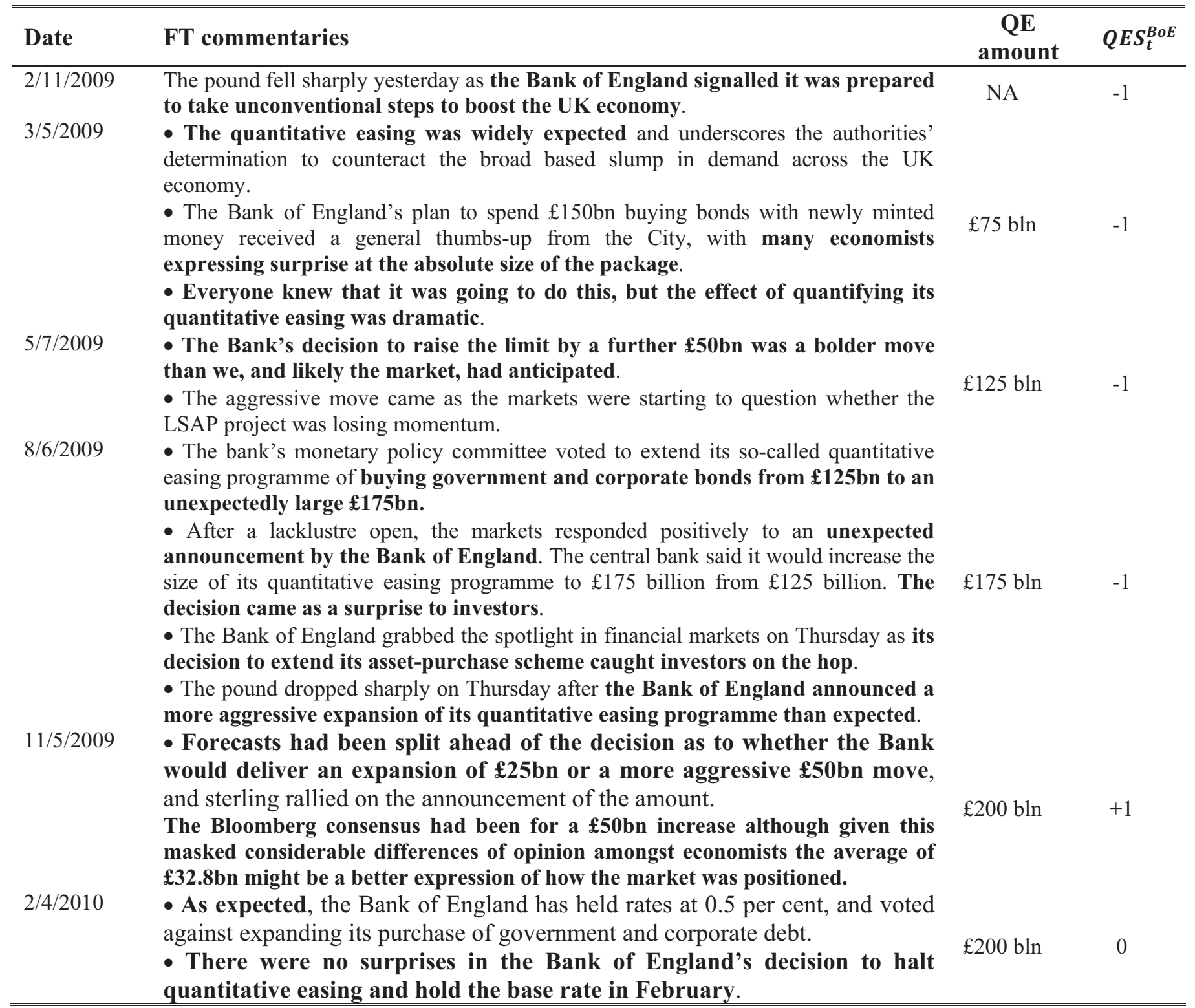




\section{Appendix B: Data cleaning procedure}

In a large high-frequency dataset erroneous data due to human input errors as well as automated quoting algorithm are inevitably present, especially if the quotes are not legally binding. This Appendix outlines the step-by-step cleaning procedure that I have applied to Thomson Reuters Tick History data. ${ }^{13}$ Data cleaning aims to eliminate from ultra high-frequency time series observations that do not reflect the market activity. This Appendix does not contain new material, but the filter rules are described here to make the paper selfcontained.

I purge outliers and potential misrecordings by applying the following selection rules:

1. Delete entries for which the price/yield is zero or negative.

2. Consolidate multiple price entries per time stamp into median prices.

3. Delete entries with a time stamp outside of the normal trading session.

4. Delete days when the first time stamp occurred 3 hours after the opening of the exchange.

5. Eliminate days when the number of ticks is lower than a pre-set value (100 ticks in a day).

6. To remove potential outliers I follow a criterion that is very closely related to the procedure discussed in Barndorff-Nielsen, Hansen, Lunde and Shephard (2009) and Brownlees and Gallo (2006). More specifically, I remove observation $i$ if the condition $\left|p_{i}-\bar{p}_{i}(k)\right|>3 s_{i}(k)+\gamma$ is true. The variables $\bar{p}_{i}(k)$ and $s_{i}(k)$ denote respectively the sample median and sample standard deviation of a neighborhood of $k$ observations around (and excluding) $i$ and $\gamma$ is a granularity parameter. The neighborhood of observations is always chosen so that a given observation is compared with observations belonging to the same trading day. I set $k=60$ and $\gamma=0.02$.

${ }^{13}$ For more details on data cleaning procedures, see Barndorff-Nielsen, Hansen, Lunde and Shephard (2009), Brownless and Gallo (2006), and Gençay, Dacorogna, Muller, Pictet and Olsen (2001). Olsen data are "pre-filtered" using proprietary data cleaning technology. 
Figure 1

The response of exchange rates to the Fed's monetary policy over longer horizons

The figure shows the longer-term impact of target (TS), news shocks (NS), and LSAP news (LSAPS) on U.S. asset prices. The solid lines represent the point estimates and the shaded areas represent \pm two standard error bands. The econometric method is Ordinary Least Squares with Heteroskedasticity-Consistent standard errors. The interval spans from one day to ten days after FOMC meeting.
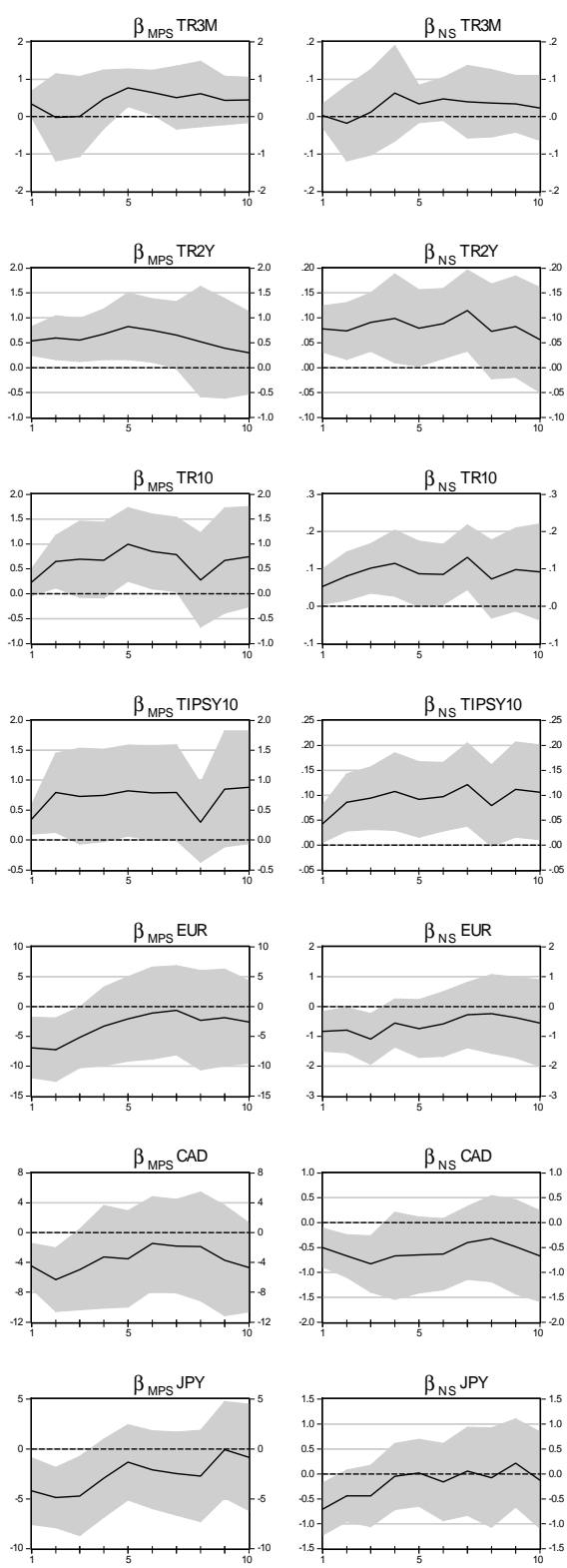
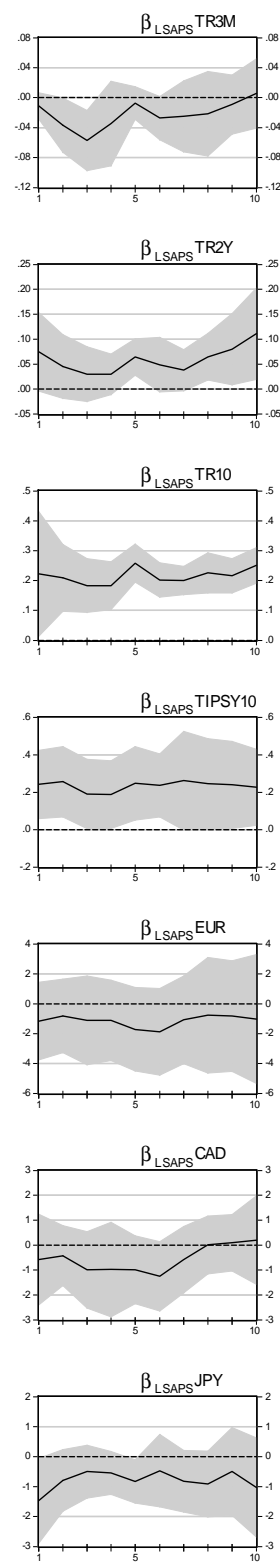
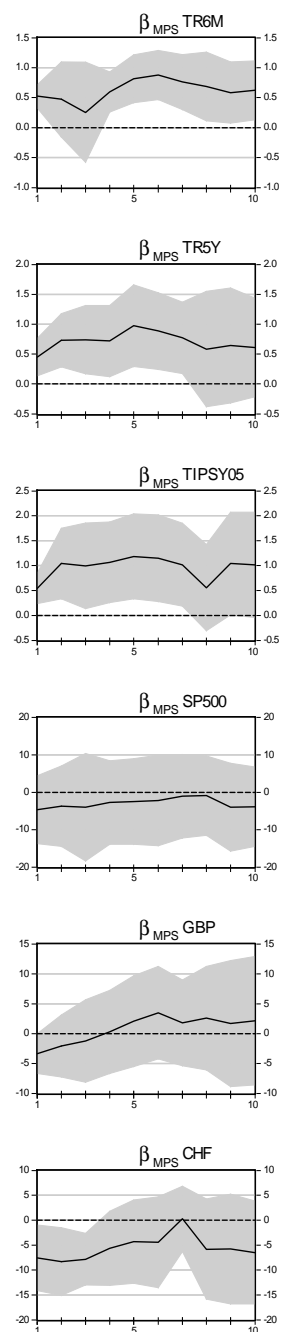
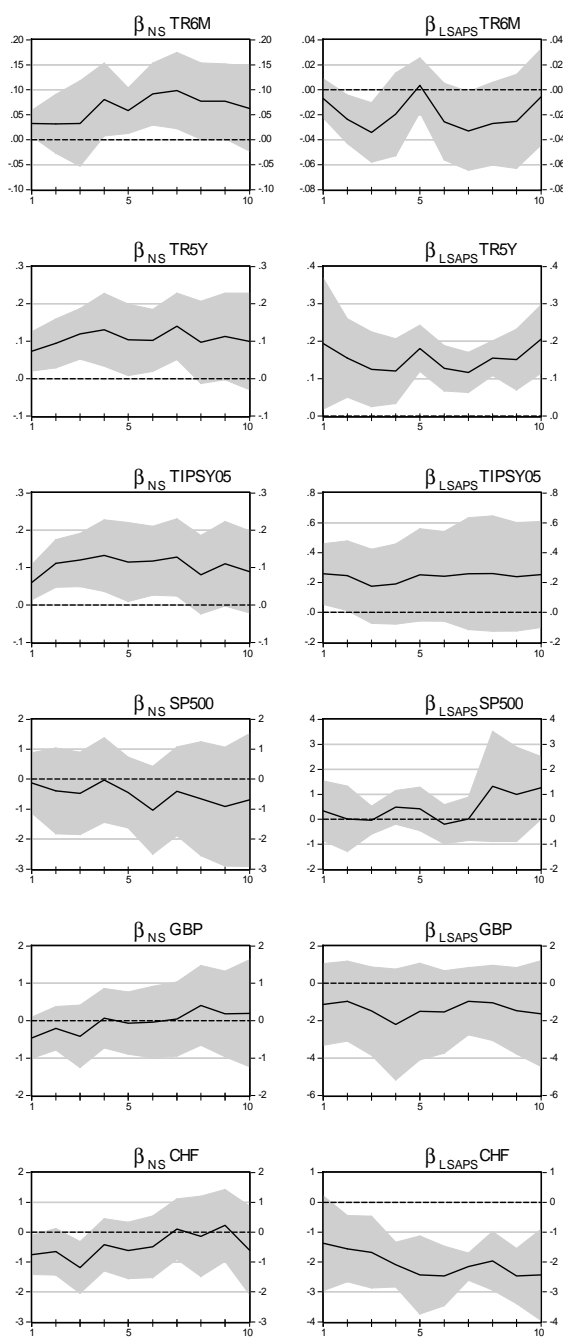
Table 1

Financial market impact of large scale asset purchases

The table summarizes some of the choices researchers have made with respect to the data and estimation method used, and reports their main findings.

\begin{tabular}{|c|c|c|c|c|}
\hline Paper & "Sample and frequency & Dependent variables & "Estimation method & Results \\
\hline $\begin{array}{l}\text { Bauer } \\
\text { Rudebusch } \\
(2011)\end{array}$ & $\begin{array}{l}\text { 1/2/1985-12/30/2009, daily } \\
\text { data }\end{array}$ & $\begin{array}{l}\text { 3-m. and 6-m. Treasury bill and 1-y., 2-y., 3- } \\
\text { y., 5-y., 7-y., 10-y. Treasury note zero- } \\
\text { coupon yields }\end{array}$ & $\begin{array}{l}\text { Discrete-time affine } \\
\text { Gaussian dynamic term } \\
\text { structure model estimated } \\
\text { by OLS, median unbiased } \\
\text { and MCMC methods. }\end{array}$ & $\begin{array}{l}\text { Large role for the signaling channel of bond purchases: for the } 10- \\
\text { year rate, the decomposition of rate changes due to portfolio } \\
\text { balance and the signaling effect is } 52 \% \text { and } 48 \% \text { respectively } \\
\text { (restricted risk price model). However, substantial estimation } \\
\text { uncertainty exists. }\end{array}$ \\
\hline $\begin{array}{l}\text { D’Amico and } \\
\text { King (2010) }\end{array}$ & $\begin{array}{l}\text { 3/25/2009-10/30/2009, } \\
\text { daily data }\end{array}$ & $\begin{array}{l}\text { Panel of CUSIP-level data of U.S. Treasury } \\
\text { securities }\end{array}$ & Two-stage least squares & $\begin{array}{l}\text { Each purchase operation ("flow effect") caused a decline in yields } \\
\text { of } 3.5 \text { basis points. The program as a whole resulted in a persistent } \\
\text { downward shift in the yield curve of } 50 \text { basis points ("stock } \\
\text { effect") }\end{array}$ \\
\hline $\begin{array}{l}\text { Gagnon, Raskin, } \\
\text { Remache and } \\
\text { Sack (2011) }\end{array}$ & $\begin{array}{l}\text { a) } 11 / 24 / 2008-3 / 31 / 2010 \text {, } \\
\text { daily data } \\
\text { b) January } 1985-J u n e ~ 2008 \text {, } \\
\text { monthly data }\end{array}$ & $\begin{array}{l}\text { a) Treasury yields, agency debt and MBS } \\
\text { yield, 10-year Treasury term premium, 10- } \\
\text { year swap rate, and Baa corporate bond index } \\
\text { yield } \\
\text { b) } 10 \text {-year term premium and Treasury yield }\end{array}$ & $\begin{array}{l}\text { a) Event-study } \\
\text { b) Dynamic OLS }\end{array}$ & $\begin{array}{l}\text { LSAP led to economically meaningful and long-lasting reductions } \\
\text { in longer-term interest rates on a range of securities. The reductions } \\
\text { in interest rates primarily reflect lower risk premia. }\end{array}$ \\
\hline $\begin{array}{l}\text { Hamilton and } \\
\text { Wu (2011) }\end{array}$ & $\begin{array}{l}\text { January } 1990 \text { - January } \\
\text { 2011, weekly data }\end{array}$ & Constant-maturity Treasury yields & $\begin{array}{l}\text { Affine term structure } \\
\text { model }\end{array}$ & $\begin{array}{l}\text { Buying } \$ 400 \text { billion in long-term maturities financed by newly } \\
\text { created reserves could reduce the } 10 \text {-year rate by } 13 \text { basis points } \\
\text { without raising short-term yields }\end{array}$ \\
\hline $\begin{array}{l}\text { Hancock and } \\
\text { Passmore (2011) }\end{array}$ & $\begin{array}{l}\text { July } 2000 \text { - November } \\
\text { 2010, weekly data }\end{array}$ & MBS yields and 7.5-year swap rate & $\begin{array}{l}\text { OLS (two-stage "mark-up" } \\
\text { model of mortgage rates) }\end{array}$ & $\begin{array}{l}\text { The announcement of the LSAP program reduced mortgage rates } \\
\text { by about } 85 \text { basis points. The purchase of MBS reduced mortgage } \\
\text { rates by roughly } 50 \text { basis points. }\end{array}$ \\
\hline $\begin{array}{l}\text { Krishnamurthy } \\
\text { and Vissing- } \\
\text { Jorgensen (2011) }\end{array}$ & $\begin{array}{l}\text { a) } 11 / 25 / 2008-11 / 3 / 2010 \text {, } \\
\text { daily and intraday data } \\
\text { b) } 1949-2008 \text {, annual data }\end{array}$ & $\begin{array}{l}\text { a) Treasury, agency and agency MBS yields, } \\
\text { corporate yields and corporate yields adjusted } \\
\text { by CDS, CDS rates, inflation swaps, TIPS } \\
\text { real yields, and implied interest rate volatility } \\
\text { b) Spread between the Moody's Baa } \\
\text { corporate bond index and the long-term } \\
\text { Treasury yield }\end{array}$ & $\begin{array}{l}\text { a) Event-study } \\
\text { b) OLS }\end{array}$ & $\begin{array}{l}\text { The results indicate a large and significant drop in nominal interest } \\
\text { rates on long-term Treasuries, Agency bonds, and highly-rated } \\
\text { corporate bonds, but only small effects on no less safe assets (Baa } \\
\text { corporate rates). The impact on MBS rates is large only when } \\
\text { LSAP involves MBS purchases. Evidence from inflation swap rates } \\
\text { and TIPS show that expected inflation increased due to both } \\
\text { LSAP1 and LSAP2 }\end{array}$ \\
\hline Neely (2010) & $\begin{array}{l}25 / 11 / 2008-11 / 4 / 2009 \text {, } \\
\text { daily and intraday data }\end{array}$ & $\begin{array}{l}\text { U.S. and foreign short-term and long-term } \\
\text { bond yields, foreign exchange value of the } \\
\text { USD, and equity prices. }\end{array}$ & Event-study & $\begin{array}{l}\text { LSAP announcements substantially reduced international long-term } \\
\text { bond yields and the spot value of the U.S. dollar. A simple } \\
\text { portfolio model explains the changes in foreign bond yields but } \\
\text { underestimates the U.S. yield changes. }\end{array}$ \\
\hline Wright (2011) & $\begin{array}{l}\text { 11/3/2008-12/28/2010, } \\
\text { daily data }\end{array}$ & $\begin{array}{l}\text { 2-y. and 10-y. Treasury yields, 5-y. } \\
\text { breakeven inflation, 5y.-5y. forward } \\
\text { breakeven, MBS yields, and BAA-AAA } \\
\text { corporate bond spread. }\end{array}$ & $\begin{array}{l}\text { Structural VAR using } \\
\text { identification } \\
\text { heteroskedasticity }\end{array}$ & $\begin{array}{l}\text { Stimulative monetary policy shocks lower Treasury and corporate } \\
\text { bond yields, but only for a short period (the estimated half-life is } \\
\text { roughly two months) }\end{array}$ \\
\hline $\begin{array}{l}\text { Joyce, Lasaosa, } \\
\text { Stevens and } \\
\text { Tong (2011) }\end{array}$ & $\begin{array}{l}\text { a) 2/11/2009-2/4/2010, } \\
\text { daily data } \\
\text { b) December 1990-June } \\
\text { 2007, monthly data }\end{array}$ & $\begin{array}{l}\text { Gilt yields, corporate bond yields, sterling } \\
\text { and FTSE all-share }\end{array}$ & $\begin{array}{l}\text { a) Event-study } \\
\text { b) OLS (Portfolio-balance } \\
\text { model) }\end{array}$ & $\begin{array}{l}\text { LSAP purchases may have depressed gilt yields by about } 100 \text { basis } \\
\text { points. The impact of LSAP on other asset prices is surrounded by } \\
\text { considerable uncertainty. }\end{array}$ \\
\hline
\end{tabular}


Table 2

Summary statistics

The table reports the summary statistics for the variables used in the econometric analysis. The sample period is May 1999 - June 2011 for the Federal Reserve, and January 1999 - June 2011 for the Bank of England, excluding all intermeeting days. The asset price return is either the change in the bond yields or the percentage change in the stock price or the U.S. dollar (GBP) bilateral exchange rate from 5-min before the FOMC (MPC) event to 25-min after the event. See the main text about the construction of the explanatory variables TS and NS.

\begin{tabular}{|c|c|c|c|c|c|c|}
\hline Variable & Mean & $\begin{array}{l}\text { Std. } \\
\text { Dev. }\end{array}$ & Max & Min & $\begin{array}{c}\text { Non-zero } \\
\text { observations }\end{array}$ & Obs. \\
\hline \multicolumn{7}{|l|}{ Federal Reserve } \\
\hline Fed funds target rate change & -0.02 & 0.24 & 0.50 & -0.75 & 41 & 97 \\
\hline TS & -0.00 & 0.05 & 0.18 & -0.25 & 68 & 97 \\
\hline Index & 0.09 & 0.68 & 1.00 & -1.00 & 45 & 97 \\
\hline NS & -0.01 & 0.35 & 0.88 & -0.90 & 96 & 97 \\
\hline \multicolumn{7}{|l|}{ U.S. asset prices } \\
\hline 3-m. Treasury & -0.01 & 0.03 & 0.09 & -0.17 & 71 & 97 \\
\hline 6-m. Treasury & -0.01 & 0.04 & 0.08 & -0.18 & 80 & 97 \\
\hline 2-y. Treasury & -0.01 & 0.06 & 0.22 & -0.17 & 85 & 97 \\
\hline 5-y. Treasury & -0.00 & 0.06 & 0.23 & -0.22 & 94 & 97 \\
\hline 10-y. Treasury & -0.00 & 0.06 & 0.16 & -0.44 & 95 & 97 \\
\hline 5-year TIPS & -0.00 & 0.05 & 0.08 & -0.19 & 58 & 58 \\
\hline 10-year TIPS & -0.00 & 0.06 & 0.10 & -0.33 & 73 & 74 \\
\hline SP 500 & -0.06 & 0.61 & 1.71 & -1.88 & 97 & 97 \\
\hline EUR-USD & 0.07 & 0.40 & 2.21 & -1.16 & 97 & 97 \\
\hline GBP-USD & 0.04 & 0.34 & 2.10 & -0.76 & 97 & 97 \\
\hline CAD-USD & 0.04 & 0.27 & 1.14 & -0.75 & 94 & 97 \\
\hline CHF-USD & 0.08 & 0.35 & 1.73 & -0.99 & 96 & 97 \\
\hline JPY-USD & 0.05 & 0.31 & 1.79 & -0.77 & 93 & 97 \\
\hline \multicolumn{7}{|l|}{ Bank of England } \\
\hline Target rate change & -0.04 & 0.21 & 0.25 & -1.50 & 29 & 152 \\
\hline$T S^{B O E}$ & -0.00 & 0.07 & 0.24 & -0.44 & 124 & 152 \\
\hline \multicolumn{7}{|l|}{ U.K. asset prices } \\
\hline 5-y. Gilts & 0.00 & 0.03 & 0.12 & -0.13 & 143 & 148 \\
\hline 10-y. Gilts & 0.00 & 0.02 & 0.09 & -0.12 & 140 & 144 \\
\hline FTSE 100 & -0.01 & 0.36 & 2.40 & -1.05 & 149 & 150 \\
\hline USD-GBP & -0.01 & 0.27 & 1.11 & -1.13 & 151 & 152 \\
\hline EUR- GBP & -0.01 & 0.26 & 0.97 & -1.08 & 152 & 152 \\
\hline CAD- GBP & -0.01 & 0.26 & 0.88 & -0.96 & 152 & 152 \\
\hline CHF- GBP & -0.02 & 0.28 & 1.04 & -1.24 & 152 & 152 \\
\hline JPY- GBP & -0.03 & 0.31 & 1.14 & -1.27 & 151 & 152 \\
\hline
\end{tabular}


Table 3

The intraday response of U.S. asset prices to the Federal Reserve monetary policy

The table reports the results from regressions of U.S. asset returns on a constant, the target, news and LSAP shock. The dependent variable is the asset price return from 5min before the event to 25-min after. Observations on days of scheduled FOMC meetings, May 1999 - June 2011. Unscheduled monetary policy meetings by the Federal Reserve are excluded. The econometric method is Ordinary Least Squares with Heteroskedasticity-Consistent standard errors in brackets. The row "Adj. ${ }^{2}$ w/o $N S_{t}$ and $L S A P S_{t}$ " reports the adjusted $\mathrm{R}^{2}$ of the estimation of a baseline specification that includes only a constant and the target shock as explanatory variables. The row "Adj. $\mathrm{R}^{2}$

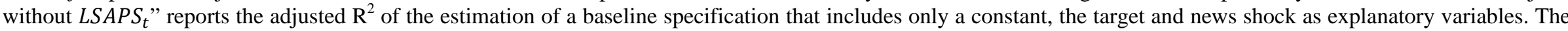
row "Cum. impact of LSAP" reports the cumulative impact of the unexpected component of the LSAP announcements expressed in federal funds target rate cut (in basis points), whereas the row " $95 \%$ c.i.” reports its $95 \%$ confidence interval. The superscripts ${ }^{* * *},{ }^{* *}$, and ${ }^{*}$ indicate statistical significance at the $1 \%$, $5 \%$ and $10 \%$ level, respectively.

\begin{tabular}{|c|c|c|c|c|c|c|c|c|c|c|c|c|c|}
\hline & 3-m. Treas. & $\begin{array}{l}\text { 6-m. } \\
\text { Treas. }\end{array}$ & $\begin{array}{l}\text { 2-y. } \\
\text { Treas. }\end{array}$ & 5-y. Treas. & $\begin{array}{l}10-y . \\
\text { Treas. }\end{array}$ & 5-y. TIPS & 10-y. TIPS & SP 500 & EUR & GBP & CAD & $\mathrm{CHF}$ & JPY \\
\hline Constant & $\begin{array}{l}-0.005^{* *} \\
(0.002)\end{array}$ & $\begin{array}{l}-0.006^{* *} \\
(0.003)\end{array}$ & $\begin{array}{l}-0.006 \\
(0.005)\end{array}$ & $\begin{array}{c}0.001 \\
(0.005)\end{array}$ & $\begin{array}{c}0.002 \\
(0.004)\end{array}$ & $\begin{array}{c}0.003 \\
(0.005)\end{array}$ & $\begin{array}{c}0.003 \\
(0.005)\end{array}$ & $\begin{array}{c}-0.109^{* *} \\
(0.051)\end{array}$ & $\begin{array}{c}0.024 \\
(0.029)\end{array}$ & $\begin{array}{l}-0.000 \\
(0.024)\end{array}$ & $\begin{array}{c}0.008 \\
(0.021)\end{array}$ & $\begin{array}{c}0.045 \\
(0.029)\end{array}$ & $\begin{array}{c}0.022 \\
(0.026)\end{array}$ \\
\hline$T S_{t}$ & $\begin{array}{l}0.461^{* * * *} \\
(0.081)\end{array}$ & $\begin{array}{l}0.555^{* * *} \\
(0.068)\end{array}$ & $\begin{array}{l}0.559^{* * * *} \\
(0.095)\end{array}$ & $\begin{array}{l}0.352^{* * * *} \\
(0.117)\end{array}$ & $\begin{array}{l}0.242^{* * *} \\
(0.098)\end{array}$ & $\begin{array}{l}0.456^{* * * *} \\
(0.123)\end{array}$ & $\begin{array}{l}0.434^{* * * *} \\
(0.105)\end{array}$ & $\begin{array}{c}-5.291^{* * *} \\
(1.504)\end{array}$ & $\begin{array}{c}-2.690^{* * *} \\
(0.818)\end{array}$ & $\begin{array}{l}-2.308^{* * *} \\
(0.670)\end{array}$ & $\begin{array}{c}-2.056^{* * * *} \\
(0.584)\end{array}$ & $\begin{array}{l}-2.084^{* * *} \\
(0.746)\end{array}$ & $\begin{array}{l}-1.254^{* *} \\
(0.584)\end{array}$ \\
\hline$N S_{t}$ & $\begin{array}{c}0.002 \\
(0.007)\end{array}$ & $\begin{array}{l}0.024^{* *} \\
(0.010)\end{array}$ & $\begin{array}{l}0.063^{* * *} \\
(0.022)\end{array}$ & $\begin{array}{l}0.057^{* *} \\
(0.022)\end{array}$ & $\begin{array}{l}0.052^{* * *} \\
(0.021)\end{array}$ & $\begin{array}{c}0.037 \\
(0.028)\end{array}$ & $\begin{array}{l}0.086^{* * * *} \\
(0.023)\end{array}$ & $\begin{array}{c}-0.579^{* * * *} \\
(0.195)\end{array}$ & $\begin{array}{c}-0.376^{* * *} \\
(0.124)\end{array}$ & $\begin{array}{l}-0.275^{* *} \\
(0.105)\end{array}$ & $\begin{array}{l}-0.208^{* * *} \\
(0.065)\end{array}$ & $\begin{array}{c}-0.308^{* * * *} \\
(0.115)\end{array}$ & $\begin{array}{l}-0.214^{* *} \\
(0.092)\end{array}$ \\
\hline$L S A P S_{t}$ & $\begin{array}{l}-0.002 \\
(0.003)\end{array}$ & $\begin{array}{l}-0.009^{*} \\
(0.004)\end{array}$ & $\begin{array}{c}0.009 \\
(0.008)\end{array}$ & $\begin{array}{l}0.085^{* *} \\
(0.040)\end{array}$ & $\begin{array}{c}0.159 \\
(0.101)\end{array}$ & $\begin{array}{l}0.078^{* * *} \\
(0.035)\end{array}$ & $\begin{array}{c}0.106 \\
(0.067)\end{array}$ & $\begin{array}{c}-0.918^{* * * *} \\
(0.141)\end{array}$ & $\begin{array}{l}-1.095^{* * *} \\
(0.333)\end{array}$ & $\begin{array}{l}-0.993^{* * *} \\
(0.371)\end{array}$ & $\begin{array}{c}-0.704^{* * *} \\
(0.092)\end{array}$ & $\begin{array}{c}-0.871^{* * *} \\
(0.248)\end{array}$ & $\begin{array}{l}-0.745^{* *} \\
(0.375)\end{array}$ \\
\hline Adj. $R^{2}$ & 0.541 & 0.553 & 0.277 & 0.209 & 0.291 & 0.301 & 0.371 & 0.300 & 0.410 & 0.418 & 0.388 & 0.323 & 0.239 \\
\hline Adj. $\mathrm{R}^{2}$ w/o $N S_{t}$ and $L S A P S_{t}$ & 0.550 & 0.518 & 0.155 & 0.035 & 0.001 & 0.138 & 0.047 & 0.122 & 0.054 & 0.063 & 0.094 & 0.036 & 0.007 \\
\hline Adj. $\mathrm{R}^{2}$ without $L S A P S_{t}$ & 0.545 & 0.556 & 0.284 & 0.153 & 0.104 & 0.193 & 0.255 & 0.238 & 0.186 & 0.166 & 0.186 & 0.146 & 0.076 \\
\hline Observations & 97 & 97 & 97 & 97 & 97 & 58 & 74 & 97 & 97 & 97 & 97 & 97 & 97 \\
\hline F-test & $38.65^{* * *}$ & $40.63^{* * *}$ & $13.24^{* * *}$ & $9.48^{* * *}$ & $14.13^{* * *}$ & $9.18^{* * *}$ & $15.36^{* * *}$ & $14.70^{* * *}$ & $23.20^{* * *}$ & $23.99^{* * *}$ & $21.26^{* * *}$ & $16.30^{* * *}$ & $11.03^{* * *}$ \\
\hline $\begin{array}{l}\text { Cum. impact of LSAP } \\
95 \% \text { c.i. }\end{array}$ & $\begin{array}{c}-1 \\
{[-5,2]}\end{array}$ & $\begin{array}{c}-5 \\
{[-10,-0]}\end{array}$ & $\begin{array}{c}5 \\
{[-3,15]}\end{array}$ & $\begin{array}{c}73 \\
{[5,244]}\end{array}$ & $\begin{array}{c}197 \\
{[-70,852]}\end{array}$ & $\begin{array}{c}51 \\
{[6,138]}\end{array}$ & $\begin{array}{c}73 \\
{[-19,194]}\end{array}$ & $\begin{array}{c}52 \\
{[28,123]}\end{array}$ & $\begin{array}{c}122 \\
{[44,331]}\end{array}$ & $\begin{array}{c}129 \\
{[33,341]}\end{array}$ & $\begin{array}{c}103 \\
{[57,244]}\end{array}$ & $\begin{array}{c}125 \\
{[47,435]}\end{array}$ & $\begin{array}{c}178 \\
{[-24,1009]}\end{array}$ \\
\hline
\end{tabular}


Table 4

The intraday response of U.S. asset prices to the Federal Reserve monetary policy

The table reports the results from the Wald test $\left(\chi^{2}\right.$ statistic) of the null hypothesis $H_{0}: \frac{\beta_{L S P S}^{(i)}}{\beta_{T S}^{(i)}}=\frac{\beta_{L S A P S}^{(j)}}{\beta_{T S}^{(j)}}$, where $\beta^{(.)}$is defined as follows:

$\left\{R_{t}^{(i)}=\beta_{0}^{(i)}+\beta_{T S}^{(i)} T S_{t}+\beta_{N S}^{(i)} N S_{t}+\beta_{L S A P S}^{(i)} L S A P S_{t}+\varepsilon_{t}^{(i)}\right.$

$\left\{R_{t}^{(j)}=\beta_{0}^{(j)}+\beta_{T S}^{(j)} T S_{t}+\beta_{N S}^{(j)} N S_{t}+\beta_{L S A P S}^{(j)} L S A P S_{t}+\varepsilon_{t}^{(j)}\right.$

The dependent variable is the asset price return from 5-min before the event to 25-min after. Observations on days of scheduled FOMC meetings, May 1999 - June 2011. Unscheduled monetary policy meetings by the Federal Reserve are excluded. The system is estimated by Seemingly Unrelated Regression (SUR) method to accounts for heteroskedasticity and contemporaneous correlation in the errors across equations. The superscripts ${ }^{* * *},{ }^{* *}$, and ${ }^{*}$ indicate statistical significance at the $1 \%$, $5 \%$ and $10 \%$ level, respectively.

\begin{tabular}{|c|c|c|c|c|c|c|c|c|c|c|c|c|}
\hline & 6-m. Treas. & 2-y. Treas. & 5-y. Treas. & 10-y. Treas. & 5-y. TIPS & 10-y. TIPS & SP 500 & EUR & GBP & CAD & $\mathrm{CHF}$ & JPY \\
\hline 3-m. Treasury & 0.27 & 0.19 & $5.23^{* *}$ & $4.68^{* *}$ & $6.66^{* * *}$ & $8.11^{* * *}$ & $5.93^{* *}$ & $12.70^{* * *}$ & $13.43^{* * *}$ & $12.88^{* * *}$ & $8.94^{* * * *}$ & $4.46^{* *}$ \\
\hline 6-m. Treasury & & 0.64 & $6.14^{* *}$ & $4.87^{* *}$ & $7.44^{* * *}$ & $8.92^{* * *}$ & $7.45^{* * *}$ & $13.84^{* * *}$ & $14.72^{* * *}$ & $14.55^{* * *}$ & $9.55^{* * *}$ & $4.63^{* *}$ \\
\hline 2-y. Treasury & & & $7.56^{* * *}$ & $4.72^{* *}$ & $4.92^{* *}$ & $7.44^{* * *}$ & $4.22^{* *}$ & $12.16^{* * *}$ & $12.76^{* * * *}$ & $11.63^{* * *}$ & $8.69^{* * *}$ & $4.35^{* *}$ \\
\hline 5-y. Treasury & & & & $3.16^{*}$ & 0.66 & 0.02 & 0.34 & 2.24 & 2.61 & 0.76 & 2.03 & 2.07 \\
\hline 10-y. Treasury & & & & & $3.34^{*}$ & 2.44 & 2.46 & 0.89 & 0.73 & 1.18 & 0.85 & 0.06 \\
\hline 5-y. TIPS & & & & & & 1.66 & 0.00 & $3.17^{*}$ & $3.37^{*}$ & 2.24 & $2.99^{*}$ & $2.71^{*}$ \\
\hline 10-y. TIPS & & & & & & & 0.42 & 0.92 & 1.23 & 0.61 & 1.00 & 1.54 \\
\hline SP 500 & & & & & & & & $4.26^{* *}$ & $5.18^{* *}$ & $4.72^{* * *}$ & $2.82^{*}$ & 2.03 \\
\hline EUR & & & & & & & & & 0.34 & 0.67 & 0.04 & 0.67 \\
\hline GBP & & & & & & & & & & 1.04 & 0.03 & 0.49 \\
\hline CAD & & & & & & & & & & & 0.45 & 0.84 \\
\hline $\mathrm{CHF}$ & & & & & & & & & & & & 0.77 \\
\hline
\end{tabular}


Table 5

The response of equity indices to the Federal Reserve monetary policy: Empirical Likelihood, Exponential Tilting, and Continuously Updating Estimator

The table reports the results from regressions of U.S. asset returns on a constant, the target, news and LSAP shock. The dependent variable is the asset price return from 5min before the event to 25-min after. Observations on days of scheduled MPC meetings, May 1999 - June 2011. The econometric method is Empirical Likelihood (EL), Exponential Tilting (ET), and Continuously Updating Estimator (CUE). For EL, ET and CUE, I use the following conditional moment restrictions: $E\left[\varepsilon_{t} \cdot f\left(X_{t}\right)\right]=0$, where $f\left(X_{t}\right)=\left\{1, X_{t}, X_{t}^{2}, X_{t}^{3}, L S A P S_{t}\right\}$ and $X_{t}=\left\{T S_{t}, N S_{t}\right\}$. The superscripts ${ }^{* * * * * *}$, and ${ }^{*}$ indicate statistical significance at the $1 \%$, $5 \%$ and $10 \%$ level, respectively.

\begin{tabular}{|c|c|c|c|c|c|c|c|c|c|c|c|c|c|}
\hline & 3-m. Treas. & $\begin{array}{l}\text { 6-m. } \\
\text { Treas. }\end{array}$ & 2-y. Treas. & 5-y. Treas. & 10-y. Treas. & 5-y. TIPS & 10-y. TIPS & SP 500 & EUR & GBP & CAD & $\mathrm{CHF}$ & JPY \\
\hline & \multicolumn{13}{|c|}{ Empirical Likelihood } \\
\hline Constant & $\begin{array}{l}-0.003 \\
(0.002)\end{array}$ & $\begin{array}{c}-0.007^{* * * *} \\
(0.002)\end{array}$ & $\begin{array}{l}-0.008^{*} \\
(0.004)\end{array}$ & $\begin{array}{c}0.001 \\
(0.005)\end{array}$ & $\begin{array}{c}0.001 \\
(0.004)\end{array}$ & $\begin{array}{c}0.005 \\
(0.004)\end{array}$ & $\begin{array}{c}0.006 \\
(0.004)\end{array}$ & $\begin{array}{c}-0.098^{* *} \\
(0.047)\end{array}$ & $\begin{array}{c}0.009 \\
(0.027)\end{array}$ & $\begin{array}{l}-0.016 \\
(0.021)\end{array}$ & $\begin{array}{c}0.003 \\
(0.019)\end{array}$ & $\begin{array}{c}0.034 \\
(0.026)\end{array}$ & $\begin{array}{r}0.025 \\
(0.022)\end{array}$ \\
\hline$T S_{t}$ & $\begin{array}{l}0.473^{* * *} \\
(0.032)\end{array}$ & $\begin{array}{l}0.529^{* * * *} \\
(0.029)\end{array}$ & $\begin{array}{l}0.537^{* * * *} \\
(0.069)\end{array}$ & $\begin{array}{l}0.284^{* * * *} \\
(0.055)\end{array}$ & $\begin{array}{l}0.150^{* * * *} \\
(0.047)\end{array}$ & $\begin{array}{l}0.351^{* * *} \\
(0.083)\end{array}$ & $\begin{array}{l}0.447^{* * * *} \\
(0.064)\end{array}$ & $\begin{array}{c}-5.895^{* * * *} \\
(1.331)\end{array}$ & $\begin{array}{c}-1.514^{* * * *} \\
(0.328)\end{array}$ & $\begin{array}{c}-1.572^{* * *} \\
(0.329)\end{array}$ & $\begin{array}{c}-1.964^{* * *} \\
(0.372)\end{array}$ & $\begin{array}{l}-0.802^{*} \\
(0.446)\end{array}$ & $\begin{array}{c}-1.128^{* * * *} \\
(0.286)\end{array}$ \\
\hline$N S_{t}$ & $\begin{array}{c}0.004 \\
(0.007)\end{array}$ & $\begin{array}{l}0.029^{* * *} \\
(0.006)\end{array}$ & $\begin{array}{l}0.048^{* * * *} \\
(0.014)\end{array}$ & $\begin{array}{l}0.046^{* * * *} \\
(0.017)\end{array}$ & $\begin{array}{l}0.033^{* * *} \\
(0.017)\end{array}$ & $\begin{array}{l}0.056^{* * *} \\
(0.023)\end{array}$ & $\begin{array}{l}0.070^{* * * *} \\
(0.017)\end{array}$ & $\begin{array}{c}-0.790^{* * * *} \\
(0.152)\end{array}$ & $\begin{array}{c}-0.412^{* * *} \\
(0.095)\end{array}$ & $\begin{array}{c}-0.324^{* * * *} \\
(0.084)\end{array}$ & $\begin{array}{c}-0.232^{* * *} \\
(0.047)\end{array}$ & $\begin{array}{c}-0.364^{* * * *} \\
(0.091)\end{array}$ & $\begin{array}{c}-0.185^{* * * *} \\
(0.071)\end{array}$ \\
\hline \multirow[t]{2}{*}{$L S A P S_{t}$} & $\begin{array}{l}-0.000 \\
(0.002)\end{array}$ & $\begin{array}{c}-0.010^{* *} \\
(0.004)\end{array}$ & $\begin{array}{c}0.010 \\
(0.009)\end{array}$ & $\begin{array}{l}0.090^{* * *} \\
(0.04)\end{array}$ & $\begin{array}{c}0.117 \\
(0.087)\end{array}$ & $\begin{array}{l}0.056^{* *} \\
(0.023)\end{array}$ & $\begin{array}{c}0.064 \\
(0.047)\end{array}$ & $\begin{array}{c}-0.857^{* * * *} \\
(0.1)\end{array}$ & $\begin{array}{c}-1.002^{* * * *} \\
(0.309)\end{array}$ & $\begin{array}{c}-0.893^{* * * *} \\
(0.337)\end{array}$ & $\begin{array}{c}-0.702^{* * * *} \\
(0.084)\end{array}$ & $\begin{array}{c}-0.802^{* * * *} \\
(0.229)\end{array}$ & $\begin{array}{c}-0.493^{*} \\
(0.29)\end{array}$ \\
\hline & \multicolumn{13}{|c|}{ Exponential Tilting } \\
\hline Constant & $\begin{array}{l}-0.002 \\
(0.002)\end{array}$ & $\begin{array}{c}-0.005^{* * * *} \\
(0.002)\end{array}$ & $\begin{array}{l}-0.007^{*} \\
(0.004)\end{array}$ & $\begin{array}{c}0.001 \\
(0.005)\end{array}$ & $\begin{array}{c}0.002 \\
(0.004)\end{array}$ & $\begin{array}{c}0.006 \\
(0.004)\end{array}$ & $\begin{array}{l}0.009^{* *} \\
(0.004)\end{array}$ & $\begin{array}{c}-0.099^{* *} \\
(0.046)\end{array}$ & $\begin{array}{c}0.011 \\
(0.027)\end{array}$ & $\begin{array}{l}-0.012 \\
(0.02)\end{array}$ & $\begin{array}{c}0.004 \\
(0.019)\end{array}$ & $\begin{array}{c}0.029 \\
(0.025)\end{array}$ & $\begin{array}{c}0.010 \\
(0.023)\end{array}$ \\
\hline$T S_{t}$ & $\begin{array}{l}0.474^{* * * *} \\
(0.033)\end{array}$ & $\begin{array}{l}0.512^{* * * *} \\
(0.028)\end{array}$ & $\begin{array}{l}0.496^{* * * *} \\
(0.069)\end{array}$ & $\begin{array}{l}0.279^{* * * *} \\
(0.055)\end{array}$ & $\begin{array}{l}0.140^{* * *} \\
(0.047)\end{array}$ & $\begin{array}{l}0.321^{* * * *} \\
(0.071)\end{array}$ & $\begin{array}{l}0.400^{* * * *} \\
(0.064)\end{array}$ & $\begin{array}{c}-6.024^{* * * *} \\
(1.321)\end{array}$ & $\begin{array}{c}-1.503^{* * * *} \\
(0.321)\end{array}$ & $\begin{array}{c}-1.415^{* * * *} \\
(0.282)\end{array}$ & $\begin{array}{c}-1.948^{* * * *} \\
(0.371)\end{array}$ & $\begin{array}{l}-0.839^{*} \\
(0.493)\end{array}$ & $\begin{array}{l}-0.903^{*} \\
(0.511)\end{array}$ \\
\hline$N S_{t}$ & $\begin{array}{r}0.008 \\
(0.006)\end{array}$ & $\begin{array}{l}0.027^{* * *} \\
(0.006)\end{array}$ & $\begin{array}{l}0.044^{* * * *} \\
(0.014)\end{array}$ & $\begin{array}{l}0.045^{* * * *} \\
(0.017)\end{array}$ & $\begin{array}{l}0.034^{* * *} \\
(0.016)\end{array}$ & $\begin{array}{l}0.063^{* * * *} \\
(0.022)\end{array}$ & $\begin{array}{l}0.071^{* * * *} \\
(0.015)\end{array}$ & $\begin{array}{c}-0.765^{* * * *} \\
(0.161)\end{array}$ & $\begin{array}{c}-0.402^{* * *} \\
(0.096)\end{array}$ & $\begin{array}{c}-0.292^{* * *} \\
(0.08)\end{array}$ & $\begin{array}{c}-0.229^{* * *} \\
(0.047)\end{array}$ & $\begin{array}{c}-0.356^{* * * *} \\
(0.096)\end{array}$ & $\begin{array}{c}-0.217^{* * * *} \\
(0.075)\end{array}$ \\
\hline \multirow[t]{2}{*}{$L S A P S_{t}$} & $\begin{array}{l}-0.001 \\
(0.002)\end{array}$ & $\begin{array}{c}-0.008^{* *} \\
(0.004)\end{array}$ & $\begin{array}{r}0.012 \\
(0.01)\end{array}$ & $\begin{array}{l}0.090^{* * *} \\
(0.041)\end{array}$ & $\begin{array}{c}0.111 \\
(0.086)\end{array}$ & $\begin{array}{l}0.056^{* * * *} \\
(0.021)\end{array}$ & $\begin{array}{r}0.047 \\
(0.03)\end{array}$ & $\begin{array}{c}-0.867^{* * *} \\
(0.102)\end{array}$ & $\begin{array}{c}-0.969^{* * *} \\
(0.298)\end{array}$ & $\begin{array}{c}-0.806^{* * *} \\
(0.297)\end{array}$ & $\begin{array}{c}-0.701^{* * * *} \\
(0.084)\end{array}$ & $\begin{array}{c}-0.733^{* * *} \\
(0.197)\end{array}$ & $\begin{array}{l}-0.505^{*} \\
(0.284)\end{array}$ \\
\hline & \multicolumn{13}{|c|}{ Continuously Updating Estimator } \\
\hline Constant & $\begin{array}{l}-0.002 \\
(0.002)\end{array}$ & $\begin{array}{c}-0.005^{* * *} \\
(0.002)\end{array}$ & $\begin{array}{l}-0.006 \\
(0.004)\end{array}$ & $\begin{array}{c}0.004 \\
(0.004)\end{array}$ & $\begin{array}{c}0.001 \\
(0.004)\end{array}$ & $\begin{array}{c}0.006^{*} \\
(0.004)\end{array}$ & $\begin{array}{r}0.005 \\
(0.004)\end{array}$ & $\begin{array}{c}-0.096^{* *} \\
(0.044)\end{array}$ & $\begin{array}{c}0.011 \\
(0.026)\end{array}$ & $\begin{array}{l}-0.007 \\
(0.019)\end{array}$ & $\begin{array}{c}0.003 \\
(0.018)\end{array}$ & $\begin{array}{c}0.022 \\
(0.025)\end{array}$ & $\begin{array}{c}0.014 \\
(0.022)\end{array}$ \\
\hline$T S_{t}$ & $\begin{array}{c}0.492^{* * * *} \\
(0.03)\end{array}$ & $\begin{array}{l}0.510^{* * * *} \\
(0.019)\end{array}$ & $\begin{array}{l}0.419^{* * * *} \\
(0.044)\end{array}$ & $\begin{array}{l}0.203^{* * * *} \\
(0.059)\end{array}$ & $\begin{array}{l}0.108^{* *} \\
(0.043)\end{array}$ & $\begin{array}{l}0.322^{* * * *} \\
(0.048)\end{array}$ & $\begin{array}{l}0.359^{* * * *} \\
(0.072)\end{array}$ & $\begin{array}{c}-5.576^{* * *} \\
(1.266)\end{array}$ & $\begin{array}{c}-1.213^{* * * *} \\
(0.254)\end{array}$ & $\begin{array}{c}-1.387^{* * * *} \\
(0.267)\end{array}$ & $\begin{array}{c}-1.693^{* * *} \\
(0.308)\end{array}$ & $\begin{array}{l}-0.191 \\
(0.412)\end{array}$ & $\begin{array}{c}-1.007^{* * * *} \\
(0.295)\end{array}$ \\
\hline$N S_{t}$ & $\begin{array}{c}0.007 \\
(0.006)\end{array}$ & $\begin{array}{l}0.030^{* * *} \\
(0.006)\end{array}$ & $\begin{array}{l}0.036^{* * * *} \\
(0.013)\end{array}$ & $\begin{array}{l}0.054^{* * * *} \\
(0.016)\end{array}$ & $\begin{array}{c}0.019 \\
(0.013)\end{array}$ & $\begin{array}{l}0.060^{* * * *} \\
(0.022)\end{array}$ & $\begin{array}{l}0.041^{* *} \\
(0.016)\end{array}$ & $\begin{array}{c}-0.788^{* * * *} \\
(0.148)\end{array}$ & $\begin{array}{c}-0.301^{* * *} \\
(0.073)\end{array}$ & $\begin{array}{c}-0.265^{* * *} \\
(0.075)\end{array}$ & $\begin{array}{c}-0.220^{* * * *} \\
(0.046)\end{array}$ & $\begin{array}{c}-0.248^{* * * *} \\
(0.078)\end{array}$ & $\begin{array}{c}-0.137^{* *} \\
(0.059)\end{array}$ \\
\hline$L_{S A P S_{t}}$ & $\begin{array}{l}-0.001 \\
(0.002)\end{array}$ & $\begin{array}{c}-0.008^{* * *} \\
(0.004)\end{array}$ & $\begin{array}{r}0.015 \\
(0.011)\end{array}$ & $\begin{array}{l}0.088^{* * *} \\
(0.038)\end{array}$ & $\begin{array}{c}0.036^{*} \\
(0.021)\end{array}$ & $\begin{array}{l}0.052^{* * * *} \\
(0.019)\end{array}$ & $\begin{array}{c}0.026^{*} \\
(0.015)\end{array}$ & $\begin{array}{c}-0.855^{* * * *} \\
(0.096)\end{array}$ & $\begin{array}{c}-0.703^{* * *} \\
(0.034)\end{array}$ & $\begin{array}{c}-0.718^{* * * *} \\
(0.252)\end{array}$ & $\begin{array}{c}-0.701^{* * * *} \\
(0.085)\end{array}$ & $\begin{array}{c}-0.628^{* * * *} \\
(0.127)\end{array}$ & $\begin{array}{l}-0.321^{*} \\
(0.167)\end{array}$ \\
\hline Obs. & 97 & 97 & 97 & 97 & 97 & 58 & 74 & 97 & 97 & 97 & 97 & 97 & 97 \\
\hline
\end{tabular}


Table 6

\section{The intraday response of U.K. asset returns to the Bank of England monetary policy}

The table reports the results from regressions of U.K. asset returns on a constant, the target and QE shock. The dependent variable is the asset price return from 5-min before the event to 25-min after. Observations on days of scheduled MPC meetings, January 1999 - June 2011 (top table) and January 1999 - June 2011 , excluding November 6, 2008 (bottom table). The extraordinary unscheduled meeting of September 18, 2001 is excluded. The econometric method is Ordinary Least Squares with Heteroskedasticity-Consistent standard errors in brackets. The row "Adj. $\mathrm{R}^{2}$ without $Q E S_{t}^{\text {BoE}}$ " reports the adjusted $\mathrm{R}^{2}$ of the estimation of a baseline specification that includes only a constant and the target shock as explanatory variables. The row "Cum. impact of QE” reports the cumulative impact of the unexpected component of the QE announcements expressed in federal funds target rate cut (in basis points), whereas the row "95\% c.i.” reports its $95 \%$ confidence interval. The superscripts ${ }^{* * *}$, ${ }^{* *}$, and indicate statistical significance at the $1 \%, 5 \%$ and $10 \%$ level, respectively.

\begin{tabular}{|c|c|c|c|c|c|c|c|c|}
\hline & 5-y. Gilts & 10-y. Gilts & FTSE 100 & USD & EUR & CAD & CHF & JPY \\
\hline Constant & 0.002 & 0.002 & -0.014 & -0.023 & -0.021 & -0.022 & -0.030 & $-0.046^{* *}$ \\
\hline & $(0.002)$ & $(0.001)$ & $(0.027)$ & (0.018) & $(0.018)$ & (0.019) & $(0.020)$ & $(0.022)$ \\
\hline$T S_{t}^{B o E}$ & $0.220^{* * * *}$ & $0.095^{* * *}$ & $-2.333^{* * *}$ & $-1.095^{*}$ & -0.820 & $-1.129^{*}$ & -0.680 & -0.775 \\
\hline$O F S^{B O E}$ & $\begin{array}{c}(0.049) \\
0.028\end{array}$ & $\begin{array}{c}(0.035) \\
0.050\end{array}$ & $\begin{array}{l}(0.681) \\
0.128^{*}\end{array}$ & $\begin{array}{c}(0.625) \\
-0.604^{* * *}\end{array}$ & $\begin{array}{c}(0.674) \\
-0.581^{* * *}\end{array}$ & $\begin{array}{l}(0.593) \\
-0.473^{* * *}\end{array}$ & $\begin{array}{c}(0.840) \\
-0.605^{* * *}\end{array}$ & $\begin{array}{c}(0.905) \\
-0.705^{* * *}\end{array}$ \\
\hline & $(0.027)$ & $(0.030)$ & $(0.070)$ & $(0.100)$ & $(0.089)$ & $(0.103)$ & $(0.107)$ & $(0.111)$ \\
\hline Adj. $\mathrm{R}^{2}$ & 0.370 & 0.292 & 0.200 & 0.276 & 0.236 & 0.221 & 0.198 & 0.217 \\
\hline Adj. $\mathrm{R}^{2}$ without $Q E S_{t}^{B o E}$ & 0.342 & 0.124 & 0.201 & 0.117 & 0.076 & 0.121 & 0.048 & 0.052 \\
\hline Observations & 148 & 144 & 150 & 152 & 152 & 152 & 152 & 152 \\
\hline F-test & $44.17^{* * * *}$ & $30.52^{* * *}$ & $19.65^{* * *}$ & $29.80^{* * *}$ & $24.35^{* * *}$ & $22.38^{* * * *}$ & $19.63^{* * *}$ & $21.90^{* * *}$ \\
\hline $\begin{array}{l}\text { Cum. impact of QE } \\
95 \% \text { c.i. }\end{array}$ & $\begin{array}{c}38 \\
{[-39,119]}\end{array}$ & $\begin{array}{c}159 \\
{[-43,602]}\end{array}$ & $\begin{array}{c}-16 \\
{[-37,2]}\end{array}$ & $\begin{array}{c}165 \\
{[-733,1210]}\end{array}$ & $\begin{array}{c}213 \\
{[-1742,2116]}\end{array}$ & $\begin{array}{c}126 \\
{[-223,905]}\end{array}$ & $\begin{array}{c}267 \\
{[-2636,2872]}\end{array}$ & $\begin{array}{c}273 \\
{[-2838,2826]}\end{array}$ \\
\hline & 5-y. Gilts & 10-y. Gilts & FTSE 100 & USD & EUR & CAD & CHF & JPY \\
\hline Constant & $\begin{array}{c}0.002 \\
(0.002)\end{array}$ & $\begin{array}{c}0.002 \\
(0.001)\end{array}$ & $\begin{array}{l}-0.019 \\
(0.025)\end{array}$ & $\begin{array}{l}-0.015 \\
(0.017)\end{array}$ & $\begin{array}{l}-0.012 \\
(0.016)\end{array}$ & $\begin{array}{l}-0.014 \\
(0.018)\end{array}$ & $\begin{array}{l}-0.018 \\
(0.017)\end{array}$ & $\begin{array}{l}-0.033^{*} \\
(0.019)\end{array}$ \\
\hline$T S_{t}^{B o E}$ & $\begin{array}{l}0.213^{* * * *} \\
(0.066)\end{array}$ & $\begin{array}{l}0.102^{* * *} \\
(0.048)\end{array}$ & $\begin{array}{l}-1.838^{* *} \\
(0.766)\end{array}$ & $\begin{array}{c}-1.855^{* * *} \\
(0.361)\end{array}$ & $\begin{array}{c}-1.673^{* * * *} \\
(0.308)\end{array}$ & $\begin{array}{c}-1.845^{* * *} \\
(0.347)\end{array}$ & $\begin{array}{c}-1.765^{* * *} \\
(0.295)\end{array}$ & $\begin{array}{c}-1.919^{* * * *} \\
(0.392)\end{array}$ \\
\hline$Q E S_{t}^{B o E}$ & $\begin{array}{c}0.028 \\
(0.026)\end{array}$ & $\begin{array}{c}0.050 \\
(0.030)\end{array}$ & $\begin{array}{c}0.096 \\
(0.067)\end{array}$ & $\begin{array}{c}-0.555^{* * * *} \\
(0.081)\end{array}$ & $\begin{array}{c}-0.526^{* * * *} \\
(0.060)\end{array}$ & $\begin{array}{c}-0.426^{* * *} \\
(0.084)\end{array}$ & $\begin{array}{c}-0.535^{* * * *} \\
(0.071)\end{array}$ & $\begin{array}{c}-0.631^{* * * *} \\
(0.080)\end{array}$ \\
\hline Adj. $R^{2}$ & 0.307 & 0.283 & 0.101 & 0.379 & 0.361 & 0.317 & 0.356 & 0.362 \\
\hline Adj. $\mathrm{R}^{2}$ without $Q E S_{t}^{B o E}$ & 0.276 & 0.118 & 0.104 & 0.243 & 0.224 & 0.236 & 0.226 & 0.218 \\
\hline Observations & 147 & 143 & 149 & 151 & 151 & 151 & 151 & 151 \\
\hline F-test & $33.31^{* * *}$ & $29.03^{* * *}$ & $9.30^{* * * *}$ & $46.68^{* * * *}$ & $43.45^{* * *}$ & $35.87^{* * * *}$ & $42.39^{* * * *}$ & $43.47^{* * *}$ \\
\hline $\begin{array}{l}\text { Cum. impact of QE } \\
95 \% \text { c.i. }\end{array}$ & $\begin{array}{c}39 \\
{[-40,142]}\end{array}$ & $\begin{array}{c}146 \\
{[-97,874]}\end{array}$ & $\begin{array}{c}-16 \\
{[-51,11]}\end{array}$ & $\begin{array}{c}90 \\
{[54,159]}\end{array}$ & $\begin{array}{c}94 \\
{[61,158]}\end{array}$ & $\begin{array}{c}69 \\
{[36,131]}\end{array}$ & $\begin{array}{c}91 \\
{[59,148]}\end{array}$ & $\begin{array}{c}99 \\
{[61,175]}\end{array}$ \\
\hline
\end{tabular}


Table 7

The intraday response of U.K. asset prices to the Bank of England monetary policy

The table reports the results from the Wald test $\left(\chi^{2}\right.$ statistic) of the null hypothesis $H_{0}: \frac{\beta_{Q E S}^{(i)}}{\beta_{T S}^{(i)}}=\frac{\beta_{Q E S}^{(j)}}{\beta_{T S}^{(j)}}$, where $\beta^{(\cdot)}$ is defined as follows:

$\left\{R_{t}^{(i)}=\beta_{0}^{(i)}+\beta_{T S}^{(i)} T S_{t}^{B o E}+\beta_{Q E S}^{(i)} Q E S_{t}^{B o E}+\varepsilon_{t}^{(i)}\right.$

$\left\{R_{t}^{(j)}=\beta_{0}^{(j)}+\beta_{T S}^{(j)} T S_{t}^{B o E}+\beta_{Q E S}^{(j)} Q E S_{t}^{B o E}+\varepsilon_{t}^{(j)}\right.$

The dependent variable is the asset price return from 5-min before the event to 25-min after. Observations on days of scheduled MPC meetings, January 1999 - June 2011 (top table) and January 1999 - June 2011, excluding November 6, 2008 (bottom table). The extraordinary unscheduled meeting of September 18, 2001 is excluded. The system is estimated by Seemingly Unrelated Regression (SUR) method to accounts for heteroskedasticity and contemporaneous correlation in the errors across equations. The superscripts ${ }^{* * *},{ }^{* *}$, and ${ }^{*}$ indicate statistical significance at the $1 \%, 5 \%$ and $10 \%$ level, respectively.

\begin{tabular}{|c|c|c|c|c|c|c|c|}
\hline & .10-y. Gilts & "FTSE 100 & USD & EUR & CAD & CHF & JPY \\
\hline 5-y. Gilts & $7.49^{* * * *}$ & $5.97^{* *}$ & $5.67^{* *}$ & $4.56^{* *}$ & $3.63^{*}$ & $3.17^{*}$ & $3.49^{*}$ \\
\hline 10-y. Gilts & & $11.24^{* * *}$ & 0.01 & 0.37 & 0.26 & 0.67 & 0.77 \\
\hline FTSE 100 & & & $10.79^{* * *}$ & $7.78^{* * *}$ & $9.34^{* * *}$ & $4.79^{* *}$ & $5.12^{* *}$ \\
\hline USD & & & & 1.13 & 2.43 & 1.39 & 1.66 \\
\hline EUR & & & & & 2.69 & 0.97 & 0.56 \\
\hline CAD & & & & & & 2.10 & 2.28 \\
\hline CHF & & & & & & & 0.01 \\
\hline
\end{tabular}

\begin{tabular}{lccccccc}
\hline \hline & 10-y. Gilts & FTSE 100 & USD & EUR & CAD & CHF & JPY \\
\hline 5-y. Gilts & $6.03^{* *}$ & $4.33^{* * *}$ & $3.47^{*}$ & $3.74^{*}$ & 1.29 & $3.28^{*}$ & $4.10^{* *}$ \\
10-y. Gilts & & $9.06^{* * *}$ & 1.14 & 0.97 & 2.08 & 1.09 & 0.79 \\
FTSE 100 & & $11.00^{* * *}$ & $12.57^{* * *}$ & $8.31^{* * *}$ & $10.76^{* * *}$ & $10.58^{* * *}$ \\
USD & & & 0.12 & $2.98^{*}$ & 0.01 & 0.55 \\
EUR & & & & 2.70 & 0.24 & 0.05 \\
CAD & & & & & 2.14 & $2.88^{*}$ \\
CHF & & & & & & 0.25 \\
\hline \hline
\end{tabular}

